\title{
Sectorrapportage Hoger Agrarisch Onderwijs
}

Citation for published version (APA):

Allen, J. P., van Thor, J. A. F., \& Verhagen, A. M. C. (2013). Sectorrapportage Hoger Agrarisch Onderwijs. ROA. ROA Reports No. 001 https://doi.org/10.26481/umarep.2013001

Document status and date:

Published: 01/01/2013

DOI:

10.26481/umarep.2013001

Document Version:

Publisher's PDF, also known as Version of record

\section{Please check the document version of this publication:}

- A submitted manuscript is the version of the article upon submission and before peer-review. There can be important differences between the submitted version and the official published version of record.

People interested in the research are advised to contact the author for the final version of the publication, or visit the DOI to the publisher's website.

- The final author version and the galley proof are versions of the publication after peer review.

- The final published version features the final layout of the paper including the volume, issue and page numbers.

Link to publication

\footnotetext{
General rights rights.

- You may freely distribute the URL identifying the publication in the public portal. please follow below link for the End User Agreement:

www.umlib.nl/taverne-license

Take down policy

If you believe that this document breaches copyright please contact us at:

repository@maastrichtuniversity.nl

providing details and we will investigate your claim.
}

Copyright and moral rights for the publications made accessible in the public portal are retained by the authors and/or other copyright owners and it is a condition of accessing publications that users recognise and abide by the legal requirements associated with these

- Users may download and print one copy of any publication from the public portal for the purpose of private study or research.

- You may not further distribute the material or use it for any profit-making activity or commercial gain

If the publication is distributed under the terms of Article $25 \mathrm{fa}$ of the Dutch Copyright Act, indicated by the "Taverne" license above, 


\title{
Sectorrapportage Hoger Agrarisch Onderwijs
}

\author{
Jim Allen \\ Jesper van Thor \\ Annelore Verhagen
}

ROA-R-2013/1 


\section{Colofon}

(C) Researchcentrum voor Onderwijs en Arbeidsmarkt (ROA). Niets uit deze uitgave mag op enige manier worden verveelvoudigd zonder voorafgaande schriftelijke toestemming van de directeur van het ROA.

\section{Researchcentrum voor Onderwijs en Arbeidsmarkt}

School of Business and Economics

Maastricht University

\section{Vormgeving}

ROA secretariaat, Maastricht

\section{Verkoop}

Researchcentrum voor Onderwijs en Arbeidsmarkt email: secretary-roa-sbe@maastrichtuniversity.nl website: www.roa.nl

ISBN: 978-90-532I-506-7

februari 2013 


\section{Inhoud}

1 Inleiding 1

2 De arbeidsmarkt voor afgestudeerden van het HAO 7

3 Arbeidsmarktperspectieven $\quad 21$

4 Vereiste competenties voor afgestudeerden van het HAO 25

4.1 Vereist niveau competenties 25

$\begin{array}{ll}4.2 \text { Competentietekorten } & 28\end{array}$

5 Conclusie 31

Bijlage: Kernindicatoren voor HAO Bachelor-opleidingen 33 



\section{Inleiding}

De HBO-Monitor vierde in 2010 haar 20-jarige bestaan. In de eerste twintig jaar van de $\mathrm{HBO}-$ Monitor is op verschillende manieren gerapporteerd over de aansluiting tussen het $\mathrm{HBO}$ en de arbeidsmarkt, over de vraag wat de $\mathrm{HBO}$-studenten tijdens hun studie hebben geleerd en over de vraag hoe zij de gevolgde opleiding beoordelen. Hierbij is vooral gericht gerapporteerd op landelijk niveau en op het niveau van de onderwijsinstelling. De tussenliggende laag, de afzonderlijke sectoren, (met uitzondering van de sector kunst), zijn daarbij (met uitzondering van het eerste jaar van de HBO-Monitor) zelden als insteek gekozen. Voor de resterende zes sectoren: Economie, Gezondheidszorg, Landbouw, Pedagogisch, Sociaal-agogisch en Techniek wordt in het kader van het 20-jarige bestaan dan ook een rapport geschreven met de betreffende sector als centraal ankerpunt. Vanuit dit perspectief is de voorliggende rapportage specifiek gericht op de $\mathrm{HBO}$-sector Landbouw (HAO). Hierbij staan de implicaties van recente alsook toekomstige arbeidsmarktontwikkelingen in de sector op de gevraagde competenties van afgestudeerden centraal. Zo wordt achterhaald op welke competenties het onderwijsveld zich de komende jaren zou moeten richten om afgestudeerden optimaal voor te kunnen bereiden op hun beroepsloopbaan in de technisch sector.

De context van deze rapportage wordt gevormd door de strategische agenda $\mathrm{HO}$ en het hoofdlijnenakkoord tussen de HBO-raad en het Ministerie van Onderwijs,

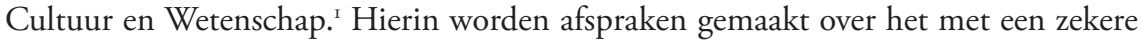
regelmaat uitvoeren van sectorale verkenningen. De huidige rapportage in het kader van 20 jaar HBO-Monitor levert relevant materiaal voor die sectorale verkenningen.

\section{Leeswijzer}

Als uitgangspunt voor voorliggende sectorrapportage wordt in hoofdstuk I allereerst kort een algemeen beeld van de sector Landbouw geschetst. Vervolgens wordt in hoofdstuk 2 aan de hand van een breed scala aan indicatoren de arbeidsmarktsituatie voor recent afgestudeerden van het Hoger Agrarisch Onderwijs beschreven. Hierna wordt in hoofdstuk 3 stilgestaan bij de verwachte arbeidsmarktperspectieven voor afgestudeerde Landbouw-studenten in de komende jaren. Tot slot wordt in hoofdstuk 4 ingegaan op de competenties die recent afgestudeerden dienen te bezitten en worden

I. Ministerie van Onderwijs, Cultuur en Wetenschap (20II), Hoofdlijnenakkoord OCW - HBO-Raad, Den Haag: OCW. 
in hoofdstuk 5 de belangrijkste conclusies op een rij gezet. In de bijlage worden de resultaten voor enkele kernindicatoren uitgesplitst naar HAO Bachelor-opleidingen.

\section{HAO cijfermatig in beeld}

Landbouw is veruit de kleinste van alle HBO sectoren. Jaarlijks staan er in totaal zo'n 8.0oo studenten ingeschreven bij een Landbouw-studie op HBO niveau, terwijl er bij de één na kleinste sector (KUO) jaarlijks al zo'n 20.000 studenten staan ingeschreven. Er zijn dan ook maar vijf $\mathrm{HBO}$ scholen waar dergelijke opleidingen gevolgd kunnen worden.

De nieuwe instroom in de sector landbouw bestaat jaarlijks uit ruim 2.000 studenten. Tabel I.I geeft voor 2010 de Io grootste landbouw opleidingen binnen het $\mathrm{HBO}$ weer. Dier- en veehouderij en Bedrijfskunde en agribusiness zijn veruit de grootste opleidingen in de sector. Dit is de afgelopen jaren niet anders geweest. Deze twee studies hebben jaarlijks ongeveer twee keer zo veel studenten als de nummer drie en vier van de grootste landbouw opleidingen: Educatie en kennismanagement groene sector en Diermanagement (beiden hadden zo'n 740 ingeschreven studenten in 20IO). Andere grote landbouw opleidingen zijn bos- en natuurbeheer, milieukunde (landbouw), plattelandsvernieuwing, tuinbouw en akkerbouw, voedingsmiddelentechnologie en land- en watermanagement. Hier staan in 2010 echter in totaal minder dan 600 studenten ingeschreven.

\section{Tabel 1.1}

De 10 grootste opleidingen binnen het Hoger Agrarisch Onderwijs in 2010

\begin{tabular}{|l|l|r|}
\hline & Opleiding: & Inschrijvingen \\
\hline 1 & dier- en veehouderij & 1.538 \\
\hline 2 & bedriffsunde en agribusiness & 1.301 \\
\hline 4 & educatie en kennismanagement groene sector & 741 \\
\hline 5 & diermanagement & 746 \\
\hline 6 & bos- en natuurbeheer & 550 \\
\hline 7 & milieukunde (landbouw) & 396 \\
\hline 8 & plattelandsvernieuwing & 381 \\
\hline 9 & tuinbouw en akkerbouw & 370 \\
\hline 10 & voedingsmiddelentechnologie & 376 \\
\hline & land- en watermanagement & 294 \\
\hline
\end{tabular}

Bron: HBO-raad² / bewerking ROA

2. HBO-raad (2OI2), Inschrijvingen: Absolute aantallen. http://cijfers.hbo-raad.nl/QvAJAXZfc/opendoc.htm?document=2_Inschrijvingen. qvw\&host=Local\&anonymous=true I3-09-20I2 


\section{Achtergrondkenmerken}

Maar hoe ziet 'de' student $\mathrm{HBO}$ landbouw er nu eigenlijk uit? Om hier kort een beeld van te schetsen worden in tabel I.2 een aantal achtergrondkenmerken van recent afgestudeerden van het Hoger Agrarisch Onderwijs weergegeven. Om deze achtergrondkenmerken te kunnen duiden worden deze bovendien vergeleken met het HBO-gemiddelde.

Tabel I.2 geeft een kort overzicht van enkele voorname achtergrondkenmerken van recent afgestudeerden van het $\mathrm{HAO}$. Deze gegevens hebben betrekking op de periode 2006-20IO. De achtergrondkenmerken van HAO'ers worden vergeleken met die van de totale groep $\mathrm{HBO}$-afgestudeerden in dezelfde periode.

Tabel $\mathbf{1 . 2}$

Achtergrondkenmerken van recent afgestudeerden van het HAO, 2006-2010

\begin{tabular}{|l|r|r|}
\hline Vrouw (\%) & HAO & HBO totaal \\
\hline Leeftijd (gem.) & 39,7 & 55,9 \\
\hline Allochtoon (\%) & 24,8 & 25,2 \\
\hline westerse & & \\
\hline niet-westerse & 3,8 & 7,2 \\
\hline Hoogst voltooide vooropleiding (\%) & 1,1 & 6,2 \\
\hline HAVO & & \\
\hline VWO & 45,2 & 48,8 \\
\hline MBO & 11,7 & 16,7 \\
\hline HBO & 38,5 & 26,8 \\
\hline andere vooropleiding & 3,4 & 5,3 \\
\hline Stage gelopen in buitenland & 1,1 & 2,3 \\
\hline Andere relevante werkervaring tijdens opleiding & 55,3 & 17,8 \\
\hline Bestuurlijke ervaring opgedaan tijdens opleiding & 67,8 & 51,7 \\
\hline Vervolgopleiding gevolgd (\%) & 39,1 & 20,6 \\
\hline Bron: HBO-Monitor $2006-2010$ & 15,0 & 22,1 \\
\hline
\end{tabular}

In vergelijking met het $\mathrm{HBO}$-gemiddelde zijn recent afgestudeerden van het $\mathrm{HAO}$ vaker man en autochtoon. Daarnaast zijn afgestudeerden van $\mathrm{HAO}$ verhoudingsgewijs vaak afkomstig van een vooropleiding op $\mathrm{MBO}$-niveau. Wat verder opvalt is dat, in vergelijking met het gemiddelde, een drie keer zo groot deel van de HAO'ers stage gelopen heeft in het buitenland. Meer dan de helft (55,3\%) van degenen die een opleiding HBO landbouw gevolgd hebben heeft stage in het buitenland gelopen. Wanneer we kijken naar de opleidingstypen binnen het $\mathrm{HAO}$, zien we dat voor al deze opleidingstypen geldt dat er vaker dan HBO-gemiddeld in het buitenland stage wordt gelopen. De opleidingstypen waar recent afgestudeerden het vaakst aangeven in het buitenland stage te hebben gelopen zijn HAO-landbouw (78\%) en $\mathrm{HAO}-$ bedrijfskunde groene sector $(50 \%)$. Ook qua opgedane relevante werkervaring 
en bestuurlijke ervaring scoren recent afgestudeerde HAO'ers I,5 jaar na afstuderen aanmerkelijk beter. De tijdens de opleiding opgedane relevante werkervaring is vooral groot onder afgestudeerden met een diploma $\mathrm{HBO}$ educatie groene sector. Van deze groep heeft 8 op de Io extra relevante werkervaring opgedaan tijdens de studie. Dit geldt in het bijzonder voor bestuurlijke ervaring die tijdens de opleiding is opgedaan. Van de totale groep recent afgestudeerde HBO'ers heeft I op de 5 tijdens de opleiding bestuurlijke ervaring opgedaan. Onder afgestudeerden van het HAO is deze groep twee maal zo groot. Afgestudeerden van het $\mathrm{HAO}$ volgen daarentegen minder dan gemiddeld een vervolgopleiding.

Tabel 1.3

Werkende recent afgestudeerden van het HAO per branche, 2006-2010 (\%)

\begin{tabular}{|c|c|c|c|}
\hline & Branche & $\begin{array}{r}\text { HAO } \\
\%\end{array}$ & $\begin{array}{r}\text { HBO totaal } \\
\%\end{array}$ \\
\hline 1 & Architecten, ingenieurs en technisch ontwerp en advies & 6,4 & 2,7 \\
\hline 2 & Fokken en houden van dieren & 6,3 & 0,3 \\
\hline 3 & Openbaar bestuur & 6,0 & 2,7 \\
\hline 4 & Voortgezet onderwijs & 5,3 & 4,2 \\
\hline 5 & Accountancy, belastingadvisering en administratie & 4,0 & 2,9 \\
\hline 6 & Groothandel in landbouwproducten en levende dieren & 3,9 & 0,2 \\
\hline 7 & Dienstverlening voor de landbouw; behandeling van gewassen en zaden na de oogst & 3,9 & 0,3 \\
\hline 8 & Teelt van eenjarige gewassen & 3,6 & 0,2 \\
\hline 9 & Groothandel in voedings- en genotmiddelen & 3,3 & 0,7 \\
\hline 10 & Vervaardiging van diervoeders & 2,8 & 0,2 \\
\hline
\end{tabular}

Bron: HBO-Monitor 2006-2010

Tabel I.3 laat zien in welke branches recent afgestudeerden van het $\mathrm{HBO}$ met een landbouw opleiding de afgelopen jaren voornamelijk werkzaam zijn. Daarin is te zien dat er sprake is van een vrij grote spreiding in de branches waar de afgestudeerden van $\mathrm{HBO}$ landbouw komen te werken. In de branche waar HAO afgestudeerden het vaakst terecht komen (architecten, ingenieurs en technisch ontwerp en advies) gaat namelijk slechts $6,4 \%$ van alle HAO afgestudeerden werken. Overigens lijkt het op het eerste oog wellicht opmerkelijk dat de meeste HAO'ers in deze branche terecht komen. Driekwart van de HAO'ers die werkzaam zijn in de branche Architecten ingenieurs en technisch ontwerp en advies is echter afkomstig van de opleiding HBO Groene Ruimte, waar onder andere plattelandsvernieuwing, tuin- en landschapsinrichting, bos- en natuurbeheer, land- en watermanagement en kust- en zeemanagement onder vallen. De HAO'ers in deze branche zijn daarom voornamelijk architecten op het gebied van natuur en milieu. Het verschil met de tweede en derde rootste groep is bovendien minimaal: 6,3\% komt in de branche Fokken en houden van dieren terecht, en $6,0 \%$ vindt een baan in het openbaar bestuur. Hoewel het om kleine verschillen gaat, is het aantal studenten dat in deze branches terecht komt wel twee keer zo groot als het aantal dat in de branche Vervaardiging van diervoeders 
$(2,8 \%)$ of Groothandel in voedings- en genotsmiddelen $(3,3 \%)$ terecht komt. Ook is te zien dat dit percentage in alle Io de branches hoger is dan gemiddeld.

In tabel I. 4 wordt eveneens weergegeven in welke branches afgestudeerden van $\mathrm{HBO}$ landbouw de afgelopen jaren de dominante groep zijn onder werkende HBO'ers. ${ }^{3}$ Dat wil zeggen dat van de recent afgestudeerde $\mathrm{HBO}^{\prime}$ ers die in die branche werken, het hoogste percentage afkomstig is van het HAO. Van de totale groep recent afgestudeerde en werkende HBO'ers heeft in de periode 2006-20IO 4,2\% een landbouw opleiding gevolgd. Daarmee is dit de kleinste groep onder werkende HBO'ers.

\section{Tabel 1.4}

Branches waar recent afgestudeerden van het HAO de dominante groep zijn onder HBO-afgestudeerden, 2006-2010 (\%)

\begin{tabular}{|l|l|r|}
\hline & Branche: & $\%$ HAO \\
\hline 1 & Fokken en houden van dieren & 92,8 \\
\hline 2 & Landschapsverzorging & 89,1 \\
\hline 3 & Veterinaire dienstverlening & 85,0 \\
\hline 4 & Dienstverlening voor de landbouw; behandeling van gewassen en zaden na de 00gst & 84,7 \\
\hline 5 & Teelt van eenjarige gewassen & 78,8 \\
\hline 7 & Vervaardiging van diervoeders & 76,4 \\
\hline 8 & Teelt van sierplanten & 72,9 \\
\hline
\end{tabular}

Bron: HBO-Monitor 2006-2010

Opmerking: Alleen branches waarbinnen ten minste $100 \mathrm{HB} 0$-afgestudeerden werkzaam zijn worden weergegeven.

Uit de tabel blijkt dat van het totale aantal werkende afgestudeerde HBO'ers het aandeel werkende afgestudeerden van de sector landbouw het hoogst ligt in de branche Fokken en houden van dieren. In deze branche is zo'n $93 \%$ van de werkende $\mathrm{HBO}$ afgestudeerden afkomstig van een $\mathrm{HBO}$ landbouw opleiding. Andere branches waar een uitzonderlijk groot deel van de werkende afgestudeerde HBO'ers een landbouw opleiding heeft voltooid zijn Landschapsverzorging, Veterinaire dienstverlening, Dienstverlening voor de landbouw (behandeling van gewassen en zaden na de oogst), Teelt van eenjarige gewassen, Vervaardiging van diervoeders en Teelt van sierplanten. In deze branches zijn ten minste 7 van de Io recent afgestudeerde HBO'ers afkomstig van een landbouw opleiding. Ook in de branche Groothandel in landbouwproducten en levende dieren heeft het merendeel van de recent afgestudeerde werkende HBO'ers een landbouw opleiding voltooid $(53,5 \%)$. Het valt op dat er 'slechts' 8 branches zijn waar afgestudeerden van het HAO de dominante groep zijn onder de $\mathrm{HBO}$-afgestudeerden. Toch is dit niet vreemd, gezien het kleine aantal studenten dat een landbouw opleiding heeft gevolgd.

3. Er zijn branches met een nog hoger aandeel afgestudeerden van het HAO, maar het gaat dan om relatief kleine branches. Derhalve worden branches met minder dan Ioo HBO-afgestudeerden hier buiten beschouwing gelaten. 
Van de recent afgestudeerden is verder bekend in welke beroepsgroep zij circa I,5 jaar na afstuderen werkzaam zijn. Uit tabel I.5 blijkt dat in de periode 2006-20IO de grootste groep landbouwers is gaan werken als Milieuhygiënist en agrarisch vertegenwoordiger $(\mathrm{I} 3,7 \%)$. Een iets kleiner aandeel ( $12,5 \%)$ was werkzaam als commercieel medewerker. Daarnaast was een deel werkzaam als agrarisch vakhoofd, assistent accountant of agrarische arbeider. Voor de overige beroepsgroepen wordt tussen 2006-20IO door minder dan 5\% van de landbouwers gekozen. De top tien beroepsgroepen gedurende de afgelopen jaren bestaat verder uit de beroepen: organisatieadviseur, commercieel medewerker, leidinggevende, procestechnoloog en architect en bouwkundig projectleider.

\section{Tabel 1.5}

Aandeel werkende recent afgestudeerden van het HTO per beroep, 2006-2010 (\%)

\begin{tabular}{|c|c|c|c|}
\hline & Beroep: & $\begin{array}{r}\text { HAO } \\
\%\end{array}$ & $\begin{array}{r}\text { HBO Totaal } \\
\%\end{array}$ \\
\hline 1 & Milieuhygiënisten en agrarisch vertegenwoordigers & 13,7 & 0,9 \\
\hline 2 & Commercieel medewerkers & 12,5 & 10,6 \\
\hline 3 & Agrarische vakhoofden & 8,2 & 0,4 \\
\hline 4 & Assistent accountants & 6,3 & 5,6 \\
\hline 5 & Agrarische arbeiders & 6,0 & 0,3 \\
\hline 6 & Organisatie-adviseurs & 4,9 & 3,8 \\
\hline 7 & Commercieel medewerkers & 4,8 & 3,4 \\
\hline 8 & Leidinggevenden & 3,0 & 1,5 \\
\hline 9 & Procestechnologen & 2,7 & 0,6 \\
\hline 10 & Architecten en bouwkundig projectleiders & 2,7 & 3,1 \\
\hline
\end{tabular}

Bron: HBO-Monitor 2006-2010 


\section{De arbeidsmarkt voor afgestudeerden van het $\mathrm{HAO}$}

In hoofdstuk 2 staat de arbeidsmarktintrede van recent afgestudeerden van het Hoger Agrarisch Onderwijs centraal. In dit hoofdstuk komen verschillende indicatoren aan bod die een indicatie geven over de transitie van het Hoger Agrarisch Onderwijs naar de arbeidsmarkt voor de periode 1998-20I0. Zodoende wordt een beeld verschaft van niet alleen de huidige situatie voor afgestudeerden van het HAO op de arbeidsmarkt, maar ook van de mate waarin die situatie stabiel is, structureel beter of slechter wordt, of gevoelig is voor de conjunctuur. De indicatoren die achtereenvolgens aan bod komen zijn het werkloosheidspercentage, het percentage tijdelijke contracten, zelfstandigen en freelancers, deeltijdwerkers, het niveau en de richting van de huidige functie, het percentage dat de aansluiting tussen onderwijs en arbeidsmarkt als voldoende of goed betitelt, de beloning, de tevredenheid met de huidige baan, het percentage dat spijt heeft van de gevolgde opleiding en tot slot het percentage dat een cursus of bedrijfsopleiding gevolgd heeft. Voor elke indicator wordt de trend voor de recent afgestudeerden van het Hoger Agrarisch Onderwijs afgezet tegen de trend van de totale groep recent afgestudeerde HBO'ers. De data hebben betrekking op de periode 1998-20IO. Het gaat hierbij om cijfers over het totale Hoger Agrarisch Onderwijs, wat betekent dat de resultaten voor de specifieke onderliggende opleidingstypen hiervan af kunnen wijken. ${ }^{4}$ Bovendien dient men er bij de interpretatie van de figuren en tabellen in dit hoofdstuk rekening mee te houden dat de resultaten vanwege de beperkte omvang van het $\mathrm{HAO}$, ieder jaar op relatief kleine aantallen zijn gebaseerd. ${ }^{5}$ Hierdoor kunnen trends een vrij grillig verloop vertonen. In de bijlage zijn voor de periode 2006-20I0 de kernindicatoren werkloosheid, werkzaam in kerndomein, inkomen huidige baan, spijt van de gekozen opleiding en tevredenheid met huidige baan weergegeven voor de afzonderlijke Bachelor-opleidingen van het Hoger Agrarisch Onderwijs. Deze cijfers worden afgezet tegen het $\mathrm{HAO}$-gemiddelde en het $\mathrm{HBO}$-gemiddelde.

\section{Werkloosheid}

Afgestudeerden van het HAO lijken I,5 jaar na afstuderen meer te merken van de conjunctuur dan andere HBO'ers. Zowel voor afgestudeerden van het $\mathrm{HAO}$ als voor de totale groep $\mathrm{HBO}$ afgestudeerden geldt dat in tijden waarin het relatief goed gaat

4. Voor meer gedetailleerde informatie op het niveau van afzonderlijke opleidingen over recent afgestudeerden van het Hoger Agrarisch Onderwijs wordt verwezen naar de HBO-Monitor Kerncijfers Online. Deze informatie is te vinden op www.roa.unimaas.nl/kerncijfers.htm

5. Voor iedere analyse wordt een minimum van 20 respondenten gehanteerd. 
met de economie de werkloosheid vrij laag is en dat het werkloosheidspercentage stijgt in tijden waarin het slechter gaat met de economie, maar dit effect is sterker voor het $\mathrm{HAO}$ dan voor de totale groep $\mathrm{HBO}$ afgestudeerden. Afgezien van een uitzondering in 2009, is het werkloosheidspercentage onder recent HAO afgestudeerden namelijk hoger dan het gemiddelde wanneer het slecht gaat met de economie. Daarentegen lag het werkloosheidspercentage van HAO afgestudeerden in de periode 1998-2000, waarin het relatief goed ging met de economie, beneden het $\mathrm{HBO}$-gemiddelde. In andere woorden lijkt het erop dat de HAO'ers in 2008 relatief zwaarder door de crisis zijn getroffen, maar dat ze zich in 2009 weer redelijk hebben weten te herstellen. Zie de bijlage voor de werkloosheidspercentages voor de HAO Bachelor-opleidingen.

Figuur 2.1

Ontwikkeling werkloosheidspercentage op enquêtemoment, 1998-2010

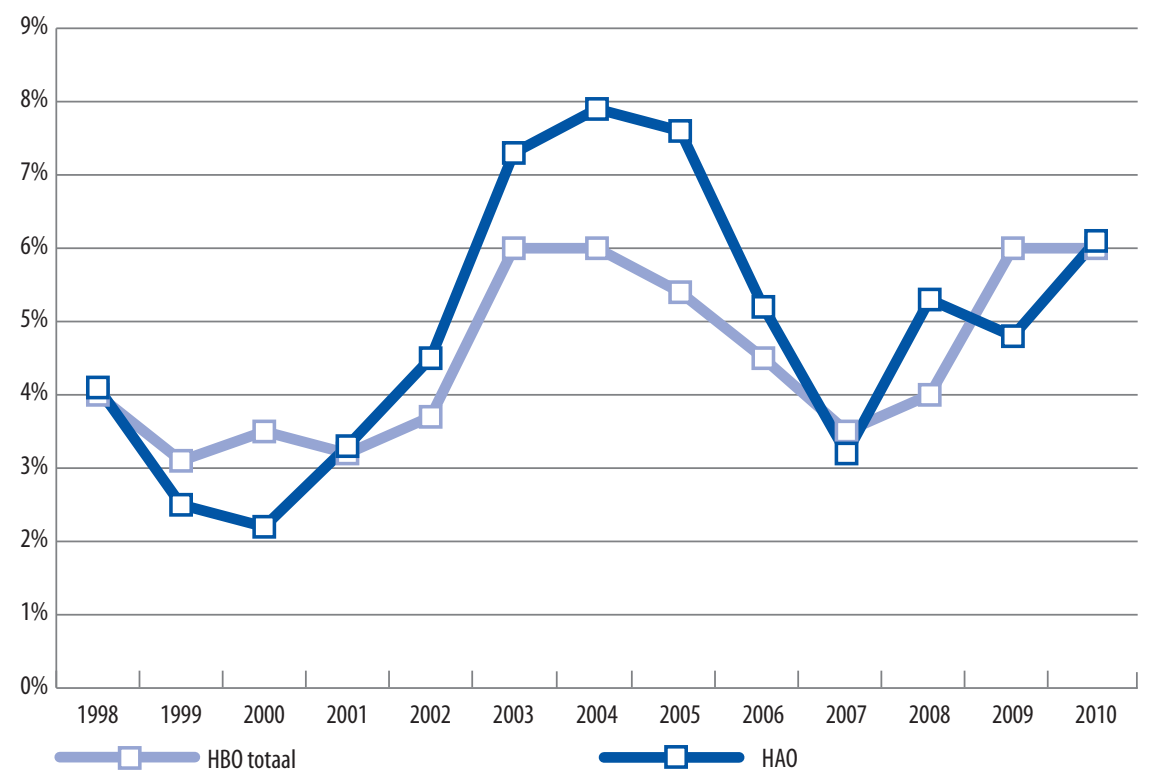

Bron: HBO-Monitor 1998-2010

\section{Tijdelijke aanstelling}

Over het algemeen zijn afgestudeerden van het Hoger Agrarisch Onderwijs kort na afstuderen vaker werkzaam onder een tijdelijke aanstelling dan andere HBO'ers. In 2005 had zelfs meer dan de helft van de recente HAO afgestudeerden geen vast contract $(54,9 \%)$. Tot 2007 volgt de trendlijn van de recent afgestudeerde landbouwers min of meer hetzelfde (conjunctuur afhankelijke) pad als die van de totale groep recent $\mathrm{HBO}$ afgestudeerden. Het percentage tijdelijke contracten voor recent afgestudeerden van het $\mathrm{HAO}$ is daarbij constant hoger dan het $\mathrm{HBO}$ gemiddelde. In 2008 
slaat dit echter om. In 2008 kreeg 'slechts' $37,4 \%$ van de recent afgestudeerde HAO'ers een tijdelijk contract: het laagste percentage in de gehele periode, waarmee het voor het eerst onder het gemiddelde zakt. In 2010 zit het percentage HAO'ers met een tijdelijk overigens alweer boven het gemiddelde en daarmee op het zelfde niveau als in 2007 , wat zou kunnen duiden op een voortzetting van de tot 2007 licht stijgende trend in het percentage tijdelijke aanstellingen. Deze stijgende trend is namelijk ook bij het $\mathrm{HBO}$-gemiddelde te zien.

\section{Figuur 2.2}

Ontwikkeling tijdelijke aanstellingen (\%), 1998-2010

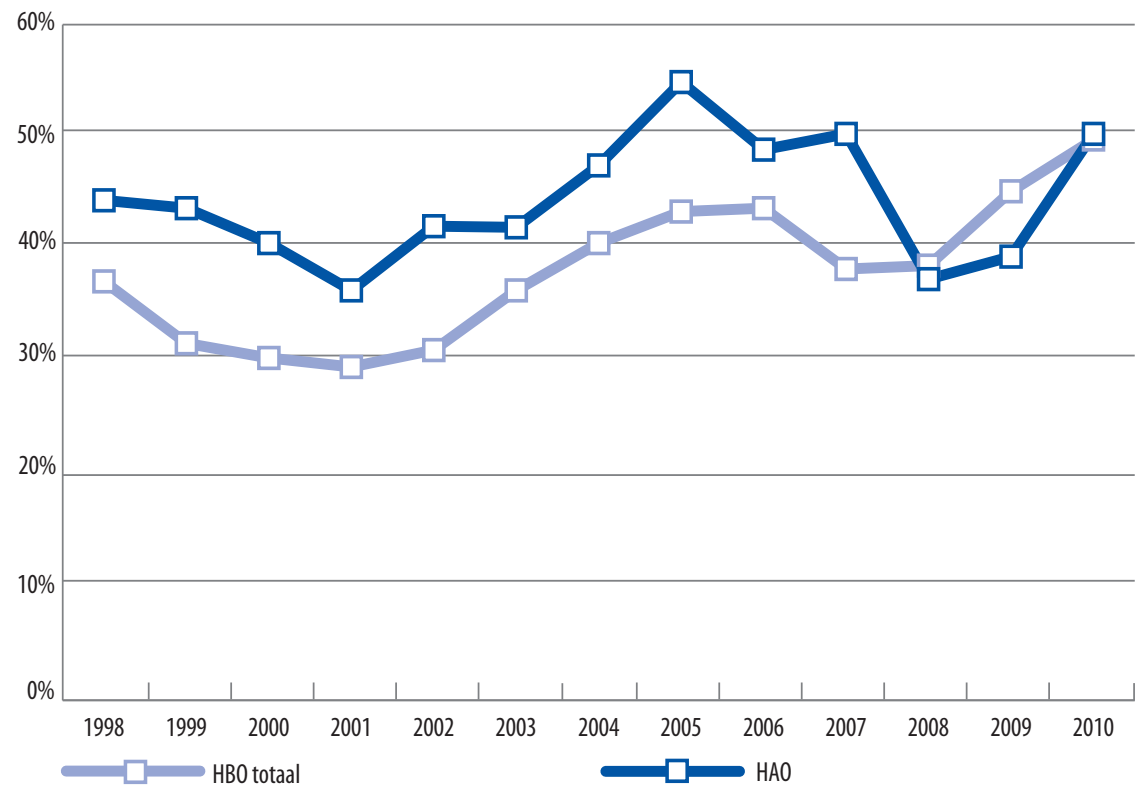

Bron: HBO-Monitor 1998-2010

\section{Aandeel zelfstandigen/freelancers}

Figuur 2.3 laat zien dat het aandeel recent afgestudeerden van $\mathrm{HBO}$ landbouw opleidingen dat als zelfstandige of freelancer aan de slag gaat over de gehele periode hoger dan gemiddeld is. Het percentage zelfstandigen/freelancers onder de HAO afgestudeerden blijft in de periode 1999-2007 echter min of meer gelijk, terwijl het $\mathrm{HBO}$-gemiddelde in die periode gestaag stijgt. In 2008 stijgt het percentage zelfstandigen/freelancers onder recent afgestudeerde landbouwers echter plotseling explosief naar 9,0\%: een percentage dat bijna twee keer zo hoog is als de jaren ervoor en als het landelijke gemiddelde van dat jaar $(5,8 \%)$. Ook in 2009 en 2010 ligt het percentage hoger dan in de periode tot 2007 , zij het in veel mindere mate. Dat het aandeel zelfstandigen/freelancers in algemene zin toeneemt, kan waarschijnlijk worden verklaard door de toenemende stimulering daarvan vanuit de overheid. De piek in 2008 in het 
aandeel afgestudeerde HAO'ers dat als zelfstandige/freelancer is gaan werken, zou wellicht het resultaat kunnen zijn van de combinatie van het begin van de economische crisis, een relatief hoog werkloosheidspercentage, en een overheidsstimulans voor ZZP'ers.

Figuur 2.3

Ontwikkeling zelfstandigen/freelancers (\%), 1998-2010

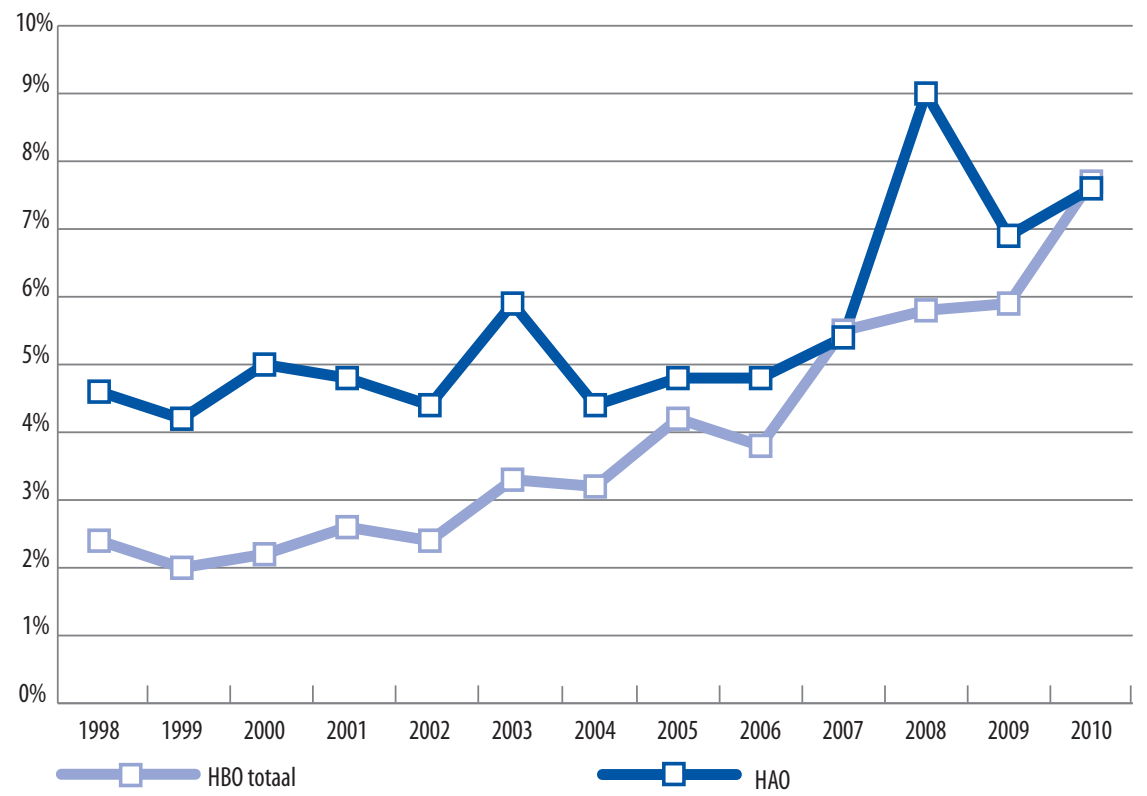

Bron: HBO-Monitor 1998-2010

\section{Parttime werk}

Ook het percentage parttimers ${ }^{6}$ kan een indicatie geven van de arbeidsmarktpositie van recent afgestudeerden. Een hoog percentage deeltijders kan er op wijzen dat afgestudeerden min of meer gedwongen genoegen moeten nemen met deeltijdbanen. Dit hoeft echter niet noodzakelijkerwijs het geval te zijn, want een deel van de parttimers zal er vrijwillig voor kiezen om minder uren te werken. Vaak gaat het hier bijvoorbeeld om vrouwen die slechts enkele dagen per week werken en dit combineren met zorgtaken.

$\mathrm{Er}$ is een stijgende trend waarneembaar in het aandeel parttime contracten, zowel onder HAO afgestudeerden als voor de totale groep HBO-afgestudeerden. In de periode I998-20Io ligt het percentage parttime contracten onder recent afgestudeerde

6. Onder parttime werkers wordt hier verstaan: alle werkenden met een contract voor 32 uur of minder per week. 
HAO'ers echter zonder uitzondering onder het $\mathrm{HBO}$-gemiddelde. Het gemiddelde percentage parttime contracten onder recent afgestudeerde HAO'ers ( $\mathrm{I} 3,7 \%)$ ligt in deze periode dan ook twee keer zo laag als het $\mathrm{HBO}$-gemiddelde van $26,5 \%$. Dit is te verklaren doordat de landbouw sector door mannen wordt gedomineerd, en mannen relatief vaak fulltime werken. Om dit te illustreren is eveneens gekeken naar het aandeel deeltijdwerkers naar geslacht voor HBO landbouw en het gehele HBO. Tussen 1998 en 2010 bedraagt het percentage deeltijdwerkers onder recent afgestudeerde mannen van het gehele $\mathrm{HBO}$ gemiddeld $13,6 \%$, onder vrouwen is dit met $36,7 \%$ duidelijk hoger. Wanneer we alleen naar HBO landbouw afgestudeerden kijken, dan blijkt het verschil in aandeel parttime contracten tussen mannen en vrouwen kleiner te zijn dan bij het $\mathrm{HBO}$ gemiddelde. Gemiddeld werkt in de periode $1998-2010$ 8,4\% van de mannelijke landbouwers parttime, en bij hun vrouwelijke studiegenoten is dit $22,6 \%$. Er lijkt hier kortom naast een geslachtseffect (mannen werken minder vaak parttime dan vrouwen, en de landbouwsector bestaat voor het merendeel uit mannen), ook sprake te zijn van een sectoreffect; zowel de mannen als de vrouwen in deze sector werken minder dan gemiddeld parttime, en het verschil tussen de percentages mannelijke en vrouwelijke parttimers is kleiner bij het $\mathrm{HAO}$ dan het $\mathrm{HBO}$-gemiddelde.

\section{Figuur 2.4}

Ontwikkeling parttime contracten (\%), 1998-2010

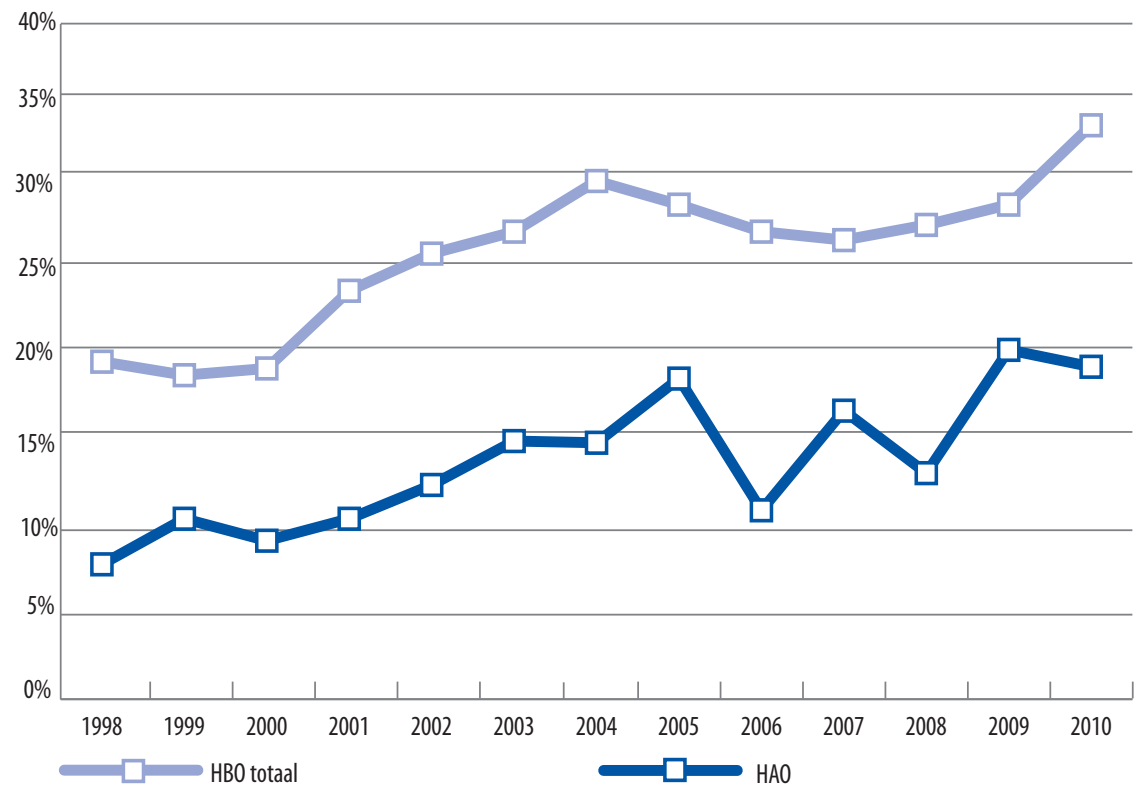

Bron: HBO-Monitor 1998-2010 


\section{Niveau en richting van de functie}

Door verdringingseffecten op de arbeidsmarkt is het mogelijk dat recent afgestudeerden noodgedwongen genoegen moeten nemen met een functie die onder hun niveau is of die buiten hun vakgebied is. Als het door de werkgever voor de functie vereiste niveau gecombineerd wordt met de vereiste opleidingsrichting kan achterhaald worden of de recent afgestudeerden werkzaam zijn in hun kerndomein. Met een baan in het kerndomein wordt bedoeld dat iemand een baan heeft op minimaal zijn opleidingsniveau (in dit geval HBO), en tegelijkertijd in dezelfde richting als de voltooide opleidingsrichting.

In de periode 1998-20I0 werken landbouwers met een HBO diploma relatief weinig binnen hun eigen opleidingsrichting en op hun eigen opleidingsniveau (in kerndomein). Van de groep afgestudeerden van landbouw werkt 'slechts' 6I,I\% binnen het kerndomein, terwijl dit voor het totale $\mathrm{HBO} 67,2 \%$ is. Dit verschil komt voor het grootste deel uit de relatief grote groep HAO'ers die onder het opleidingsniveau én buiten de opleidingsrichting (buiten het kerndomein) is gaan werken: $12,0 \%$ ten opzichte van $8,4 \%$ voor het $\mathrm{HBO}$-gemiddelde. Ook werken HAO'ers iets vaker dan de rest van het HBO buiten hun eigen richting maar op hun eigen niveau (alleen op eigen niveau), en beneden hun eigen niveau maar binnen hun eigen richting (alleen in eigen richting). In de bijlage zijn de resultaten met betrekking tot het percentage dat binnen het kerndomein werkzaam is weergegeven per HAO Bachelor-opleiding.

\section{Figuur 2.5}

Vereist niveau en vereiste richting van de baan, 1998-2010

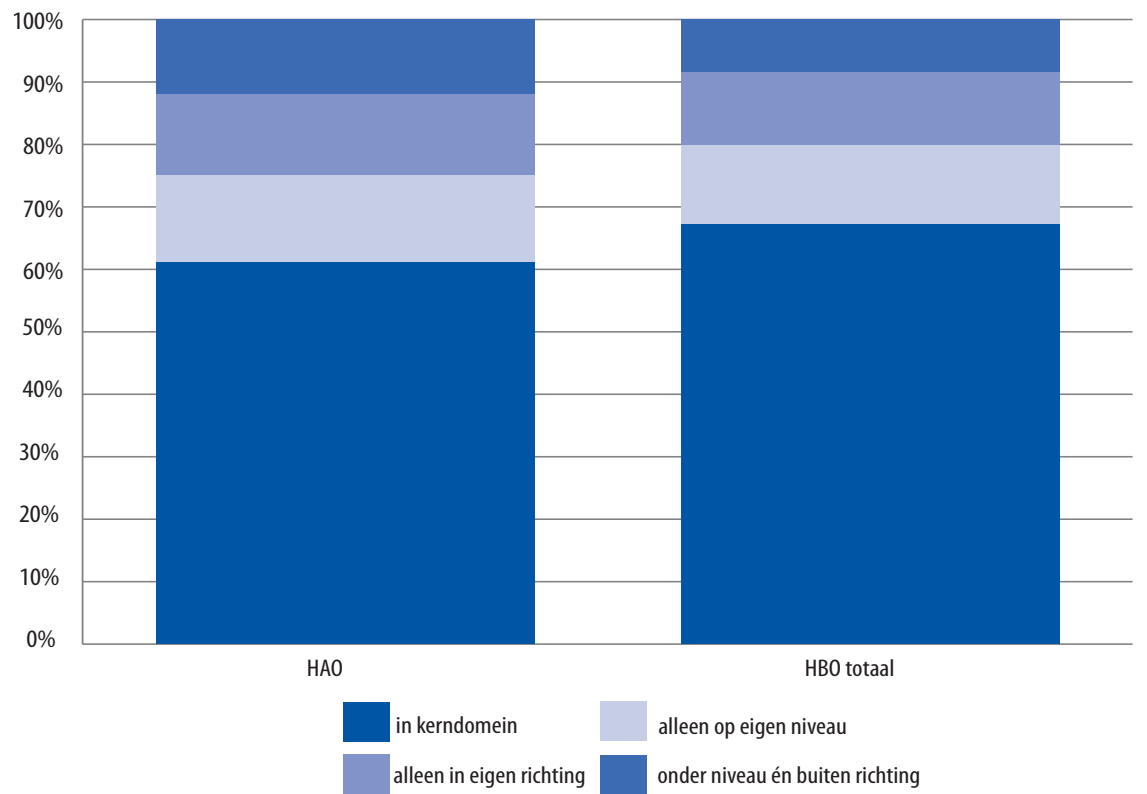


Veel van de overige baankenmerken van afgestudeerden worden in belangrijke mate bepaald door het feit of zij al dan niet binnen hun kerndomein werken. Ter illustratie wordt in tabel 2.I een overzicht gegeven van enkele baankenmerken voor afgestudeerden wiens huidige functie zowel qua niveau als richting aansluit bij de gevolgde $\mathrm{HBO}$-opleiding. Dit wordt vergeleken met afgestudeerden die respectievelijk alleen onder hun niveau werken, alleen buiten hun richting werken en zowel onder hun niveau als buiten hun richting werken.

Tabel 2.1

Baankenmerken naar werken in/buiten kerndomein, 2006-2010

\begin{tabular}{|c|c|c|c|c|c|c|}
\hline & $\begin{array}{l}\text { zelfstandige/ } \\
\text { freelancer }\end{array}$ & $\begin{array}{r}\text { tijdelijke } \\
\text { aanstelling } \\
(\%)\end{array}$ & $\begin{array}{r}\text { part-time } \\
\text { werk } \\
(\%)\end{array}$ & $\begin{array}{r}\text { aansluiting } \\
\text { opleiding-werk } \\
(\%)\end{array}$ & $\begin{array}{r}\text { gem reëel } \\
\text { uurloon }(€)\end{array}$ & $\begin{array}{l}\text { tevreden met } \\
\text { baan (\%) }\end{array}$ \\
\hline \multicolumn{7}{|l|}{ HAO } \\
\hline in kerndomein & 7,5 & 42,9 & 13,6 & 85,7 & 13,60 & 77,5 \\
\hline alleen op eigen niveau & 11,0 & 39,8 & 10,9 & 55,8 & 13,24 & 71,6 \\
\hline alleen in eigen richting & 4,7 & 43,5 & 23,2 & 71,0 & 12,12 & 61,2 \\
\hline onder niveau én buiten richting & 3,2 & 42,8 & 26,5 & 49,0 & 11,45 & 36,7 \\
\hline totaal & 7,2 & 42,5 & 15,8 & 75,5 & 13,14 & 70,2 \\
\hline \multicolumn{7}{|l|}{ HBO totaal } \\
\hline in kerndomein & 5,2 & 41,7 & 28,6 & 84,4 & 14,08 & 74,4 \\
\hline alleen op eigen niveau & 6,3 & 44,3 & 17,5 & 58,8 & 13,72 & 61,9 \\
\hline alleen in eigen richting & 3,4 & 43,6 & 41,5 & 69,8 & 12,67 & 51,5 \\
\hline onder niveau én buiten richting & 3,7 & 54,7 & 38,0 & 32,8 & 11,33 & 33,1 \\
\hline totaal & 5,1 & 43,1 & 29,2 & 76,1 & 13,69 & 67,6 \\
\hline
\end{tabular}

Bron: HBO-Monitor 2006-2010

Uit de tabel blijkt dat de afgestudeerden die binnen hun kerndomein zijn gaan werken, vergeleken met afgestudeerden in andere functies, het vaakst tevreden zijn over de aansluiting tussen opleiding en werk, dat zij het hoogste gemiddelde reële uurloon verdienen en dat zij het vaakst tevreden zijn met hun baan. Dit geldt zowel voor afgestudeerden van landbouw opleidingen als het $\mathrm{HBO}$ gemiddelde. Afgestudeerden die minimaal op hun eigen niveau maar buiten hun opleidingsrichting werken, vinden vergeleken met afgestudeerden in andere functies het vaakst een baan als zelfstandige/ freelancer (II,O\%). Zij hebben dan ook het minst vaak een tijdelijke aanstelling en/of parttime werk. De afgestudeerden van landbouw opleidingen die onder hun niveau maar binnen hun opleidingsrichting werk vinden, hebben het vaakst een tijdelijke aanstelling. Het aandeel afgestudeerden dat parttime gaat werken, is het grootst onder degenen die buiten hun kerndomein werkzaam zijn. Dit geldt zowel voor afgestudeerden van landbouw opleidingen als voor het $\mathrm{HBO}$ gemiddelde. Het is niet verras- 
send dat deze groep tevens het minst tevreden is over de aansluiting tussen opleiding en werk, het laagste reële uurloon verdient en het minst tevreden is met de baan.

In figuur 2.6 is te zien dat in de periode 1998-20Io het percentage afgestudeerde $\mathrm{HAO}$ 'ers dat binnen het kerndomein werkzaam in de gehele periode onder het $\mathrm{HBO}$ gemiddelde ligt, hoewel de verschillen in sommige jaren minimaal zijn. In 200 I en in 2004-2005 zien we een dip in het aantal afgestudeerde landbouwers dat binnen het kerndomein werkzaam is, die niet is te zien bij $\mathrm{HBO}$ gemiddelde. In de periode 2006-20IO wordt het verschil tussen het aandeel landbouwers dat binnen het kerndomein werkt en het $\mathrm{HBO}$ gemiddelde groter, omdat de dalende trend eerder bij de landbouwers wordt ingezet dan bij de rest van het $\mathrm{HBO}$.

\section{Figuur 2.6}

Ontwikkeling werkenden in kerndomein (\%), 1998-2010

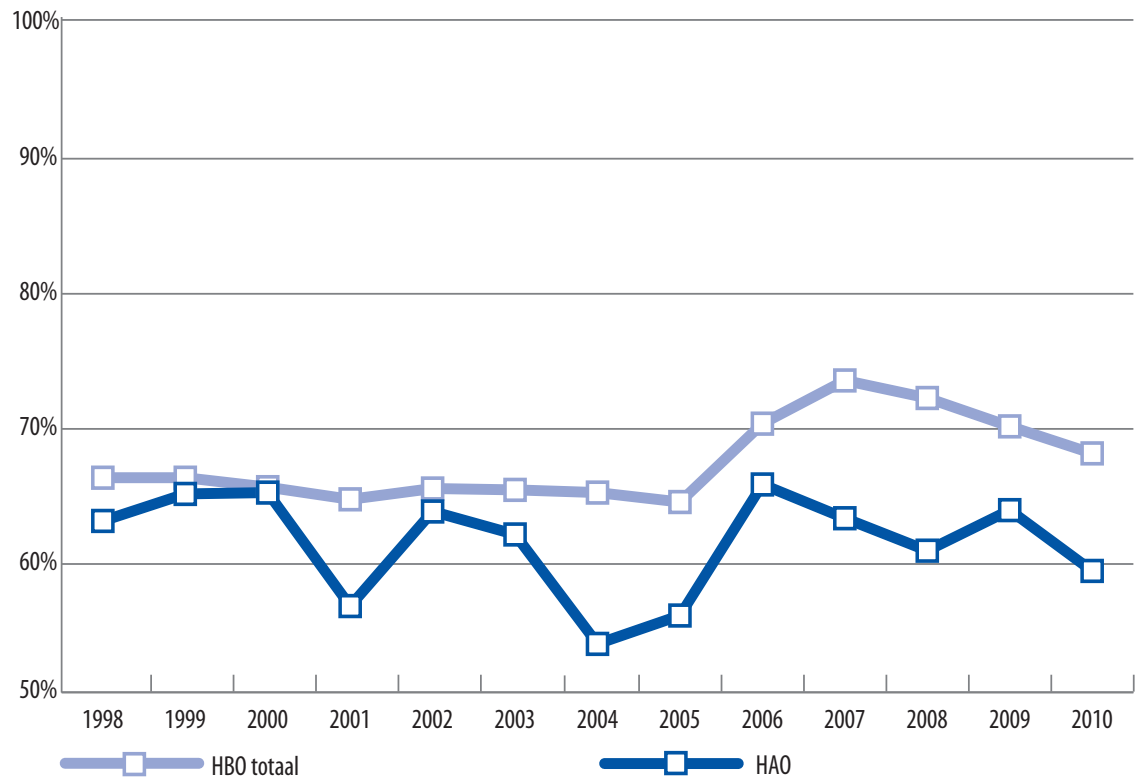

Bron: HBO-Monitor 1998-2010

\section{Aansluiting opleiding-werk}

Figuur 2.7 laat zien hoe de aansluiting tussen de gevolgde opleiding en de huidige functie ervaren is. De figuur geeft weer welk deel van de recent afgestudeerden deze aansluiting als goed of voldoende heeft ervaren. Op een dip in 2004 na, vertoont de ontwikkeling van deze indicator vrijwel een zelfde verloop voor HAO'ers als voor de totale groep afgestudeerde HBO'ers. Zowel voor het $\mathrm{HAO}$ als het $\mathrm{HBO}$-gemiddelde geldt dat recent afgestudeerden na 2002 minder vaak positief oordelen over de aanslui- 
ting tussen opleiding en werk dan in de periode daarvoor. Was in de periode 1998 2002 nog zo'n 80 tot $85 \%$ van mening dat de aansluiting voldoende/goed was, vanaf 2003 is het nog zo'n $75 \%$.

\section{Figuur 2.7}

Ontwikkeling aansluiting tussen opleiding en werk is goed/voldoende (\%), 1998-2010

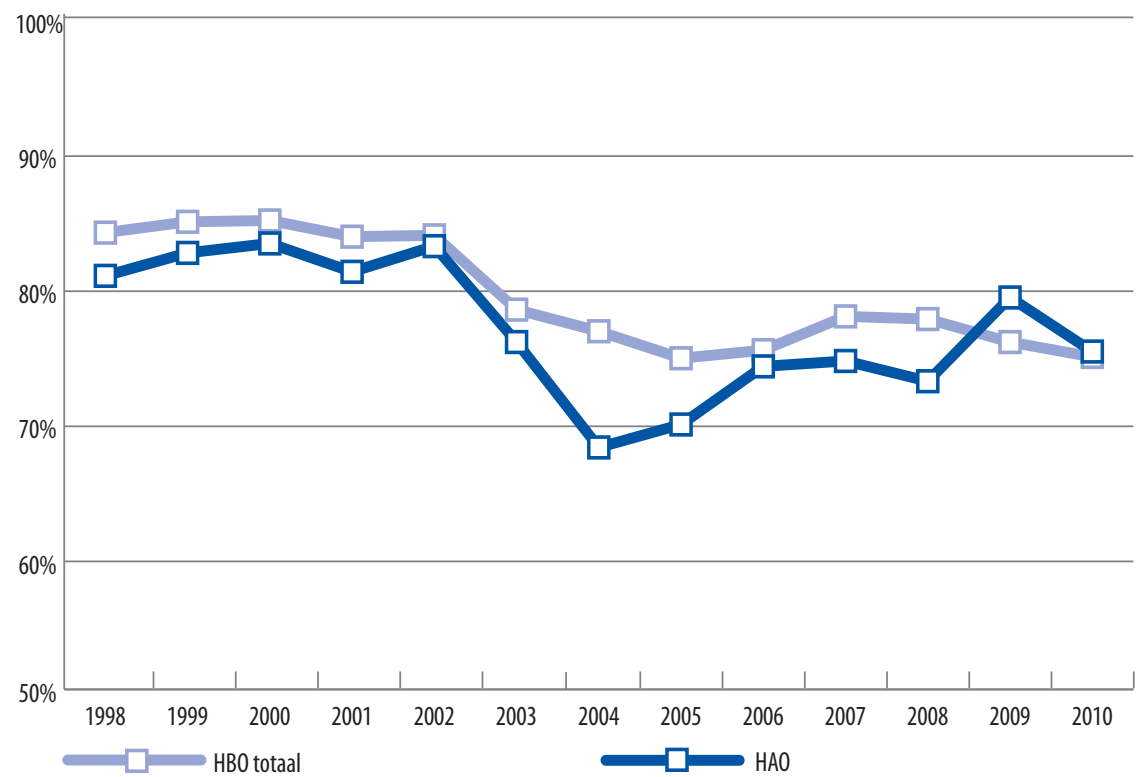

Bron: HBO-Monitor 1998-2010

Inkomen huidige baan

De startsalarissen bieden eveneens een indicatie van de arbeidsmarktpositie van recent afgestudeerden. Hieruit blijkt immers de waarde die werkgevers toekennen aan hun kwaliteiten. In figuur 2.8 is de ontwikkeling van het reële bruto uurloon van recent afgestudeerden weergegeven, van landbouw opleidingen en het HBO totaal. Hoewel het reële bruto uurloon van recent afgestudeerde landbouwers tussen 1998-2009 minstens $€ 0.45$ lager is dan het HBO gemiddelde, heeft de reële loonontwikkeling van de landbouwers min of meer hetzelfde verloop als dat van de totale groep afgestudeerde HBO'ers. In 2004 en 2005 ging het wat slechter met de economie, wat terug te zien is in de sterke daling van de reële lonen. In 2006 stijgen de lonen echter weer en in 2008 zijn de lonen van werkende HAO'ers zelfs hoger dan ze sinds 1998 zijn geweest. In 2009 dalen de lonen weer enigszins. Opvallend is dat in 2010 het reële bruto uurloon van landbouwers voor het eerst hoger is dan het $\mathrm{HBO}$ gemiddelde (+€O.I9). Zie de bijlage voor de gemiddelde bruto uurlonen per HAO Bacheloropleiding. 


\section{Figuur 2.8}

Reële ${ }^{7}$ bruto uurloon huidige baan $(€), 1998-2010$

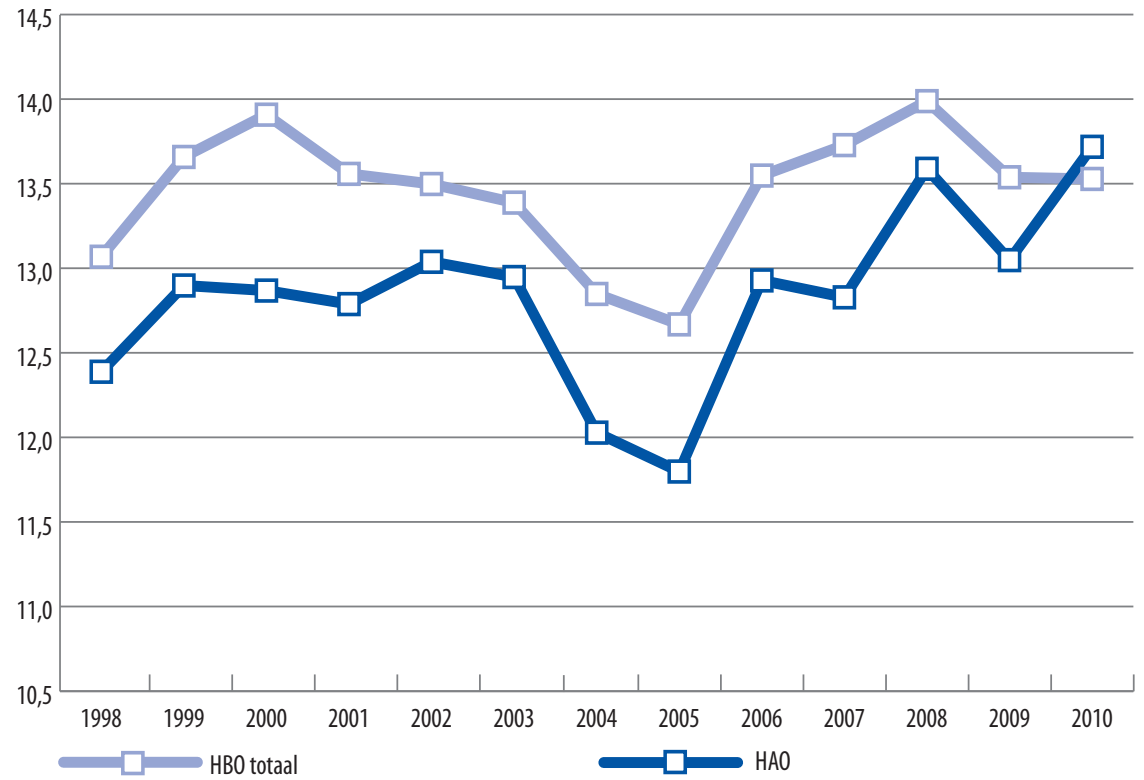

Bron: HBO-Monitor 1998-2010

\section{Tevredenheid met huidige baan}

Hoewel de verschillen gering zijn, is in figuur 2.9 te zien dat in de periode 20032007 recent afgestudeerde landbouwers I.5 jaar na afstuderen minder vaak tevreden zijn met hun functie dan het $\mathrm{HBO}$-gemiddelde. In 2008 is er echter een omslag zichtbaar; de gemiddelde HBO'er wordt vanaf dat moment minder tevreden met de functie, terwijl de afgestudeerde landbouwers vanaf dat jaar juist vaker tevreden zijn. De recent afgestudeerde landbouwers zijn in 2008-20I0 dan ook bovengemiddeld tevreden met hun functie. Zie de bijlage voor de tevredenheidspercentages per HAO Bachelor-opleiding.

7. Hierbij is gecorrigeerd voor de jaarlijkse inflatie zoals gemeten door CBS. 


\section{Figuur 2.9}

Ontwikkeling (zeer) tevreden met huidige functie (\%), 2003-2010

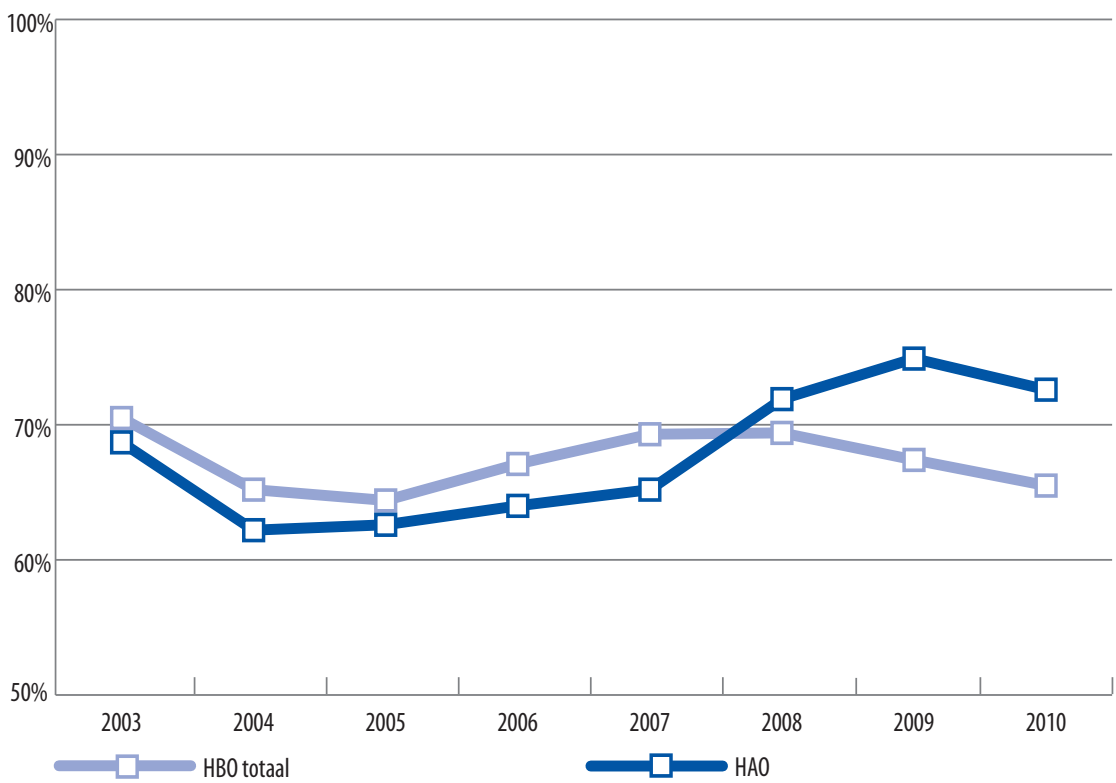

Bron: HBO-Monitor 2003-2010

\section{Spijt van de gekozen opleiding}

Aan de afgestudeerden is eveneens gevraagd of zij, achteraf bezien, opnieuw voor de eerder gevolgde HBO-opleiding zouden kiezen. Figuur 2.IO geeft voor de periode I998-20IO weer welk deel van hen achteraf spijt heeft van de gevolgde opleiding. Daarin is te zien dat in de gehele periode de afgestudeerden van landbouw opleidingen achteraf gezien vrijwel exact even vaak spijt hebben van de gevolgde opleiding als de totale groep HBO-afgestudeerden. In deze periode heeft ongeveer 2 op de IO recent afgestudeerden achteraf gezien spijt van de gevolgde opleiding. Zie de bijlage voor het percentage dat achteraf gezien spijt heeft van de gekozen opleiding, uitgesplitst naar HAO Bachelor-opleiding.

8. De variabele tevredenheid met de huidige baan is niet beschikbaar voor eerdere jaren.

Enquêtevraag: Hoe tevreden bent u met uw huidige functie (I 'zeer ontevreden' tot en met 5 'zeer tevreden'. Vermeld is het percentage van antwoordcategorie 4 en 5. 


\section{Figuur 2.10}

Achteraf gezien spijt van de gevolgde opleiding (\%), 1998-2010

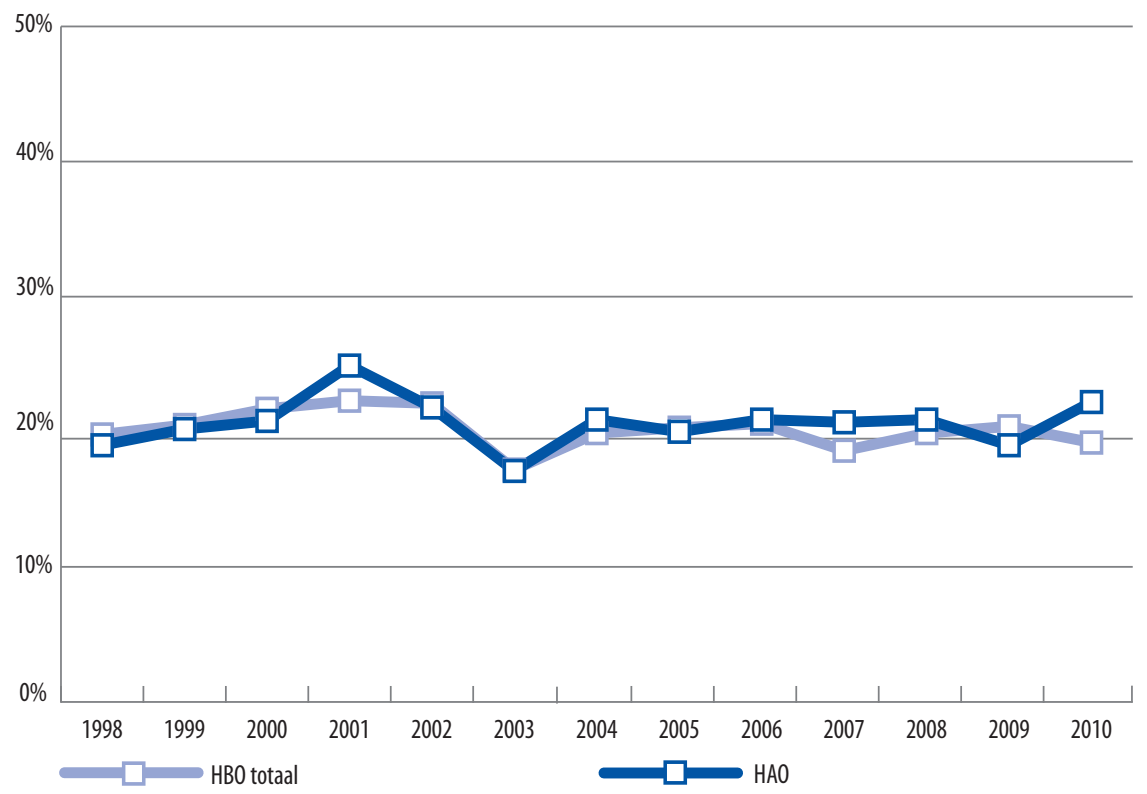

Bron: HBO-Monitor 1998-2010

\section{Cursus of bijscholing gevolgd}

Tegenwoordig wordt alom onderschreven dat de ontwikkeling van menselijk kapitaal niet op dient te houden bij het verlaten van de schoolbanken. Aangezien het belang van continue ontwikkeling en het concept van Leven Lang Leren de laatste jaren toeneemt, wordt in figuur 2.II gekeken of hier vroeg in de beroepsloopbaan al aandacht aan besteed wordt. De figuur geeft het percentage recent afgestudeerden weer dat I,5 jaar na afstuderen reeds de mogelijkheid heeft gekregen om een cursus of bedrijfsopleiding te volgen. Recent afgestudeerde HAO'ers volgen ongeveer even vaak een cursus als de gemiddelde recent afgestudeerde HBO'er. Dit is opvallend, aangezien landbouwers relatief vaker buiten hun kerndomein aan het werk zijn (en minder vaak binnen hun kerndomein). Daardoor zou je verwachten dat deze groep vaker dan gemiddeld cursussen zou volgen. Blijkbaar is dit niet nodig of zijn er andere manieren dan het volgen van een cursus of bijscholing om dit te ondervangen. 
Figuur 2.11

Cursus of bedrijfsopleiding gevolgd na HBO-opleiding (\%), 1998-2010

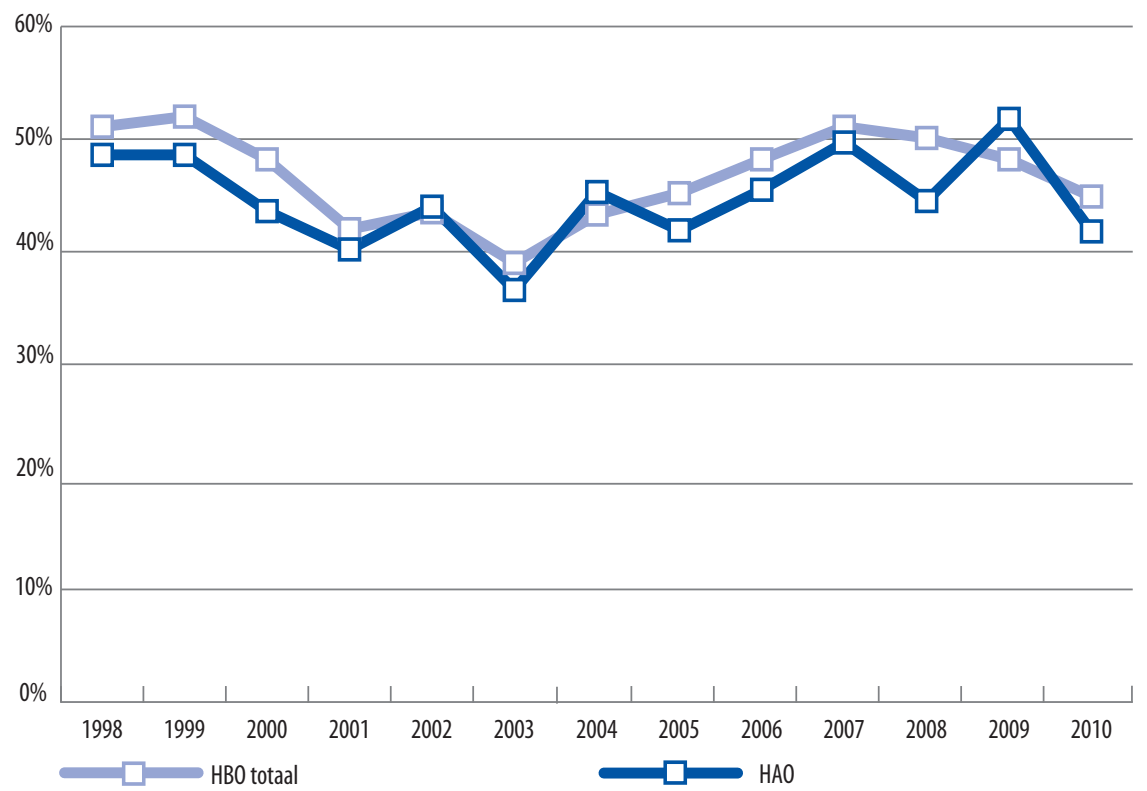

Bron: HBO-Monitor 1998-2010 



\section{Arbeidsmarktperspectieven}

In hoofdstuk 3 staan de verwachte arbeidsmarktperspectieven van tot 2016 voor HAO afgestudeerden centraal. Tweejaarlijks biedt ROA een overzicht van de huidige en toekomstige arbeidsmarktontwikkelingen. Een belangrijk onderdeel hierin zijn de arbeidsmarktperspectieven voor schoolverlaters. Het toekomstig arbeidsmarktperspectief geeft voor de verschillende opleidingstypen de verhouding weer tussen vraag en aanbod van schoolverlaters en afgestudeerden in de prognoseperiode. De vraagen aanbodprognoses zijn gebaseerd op de arbeidsmarktpositie van een opleiding in 20II. Als het arbeidsmarktperspectief van een opleiding slecht is, betekent dit dat er de komende jaren veel meer aanbod van nieuwkomers zal zijn dan dat er baanopeningen zullen ontstaan. Hierdoor zal de arbeidsmarktpositie van deze afgestudeerden verslechteren. Deze verslechtering kan tot uiting komen in een hogere werkloosheid, maar door aanpassingsprocessen op de arbeidsmarkt kan de verslechtering van de arbeidsmarktsituatie ook leiden tot het moeten aanvaarden van banen op een lager niveau, tegen een lagere beloning of bijvoorbeeld een stijging van het aantal tijdelijke contracten. Omgekeerd zal een goed perspectief leiden tot een grotere kans op werk, maar ook tot een verbeterde positie op andere punten.

Het toekomst arbeidsmarktperspectief per opleidingstype wordt bepaald door middel van de Indicator Toekomstig Arbeidsmarktperspectief (ITA)', die is gedefinieerd als de verhouding tussen enerzijds de verwachte arbeidsmarktinstroom van afgestudeerden en het aantal kortdurig werklozen en anderzijds de verwachte baanopeningen en de passieve substitutievraag. ${ }^{\text {Io }}$ Naarmate de waarde van de indicator hoger is, wordt het perspectief slechter. De bijbehorende kwalitatieve typering van de arbeidsmarktperspectieven luidt respectievelijk zeer goed, goed, redelijk, matig of slecht.

9. Zie voor meer informatie over de arbeidsmarktperspectieven van schoolverlaters: ROA (2OII), De arbeidsmarkt naar opleiding en beroep tot 2016, ROA-R-20II/8, Maastricht University.

Io. Als gevolg van discrepanties tussen vraag en aanbod op de arbeidsmarkt treden er verschuivingen op in de werkgelegenheidsstructuur. Schoolverlaters in een aanbodoverschotsituatie kunnen anders opgeleiden gaan verdringen, terwijl werkgevers die te kampen hebben met een tekortschietend arbeidsaanbod, personen met een andere opleidingsachtergrond kunnen gaan werven. De vraag die hierdoor verloren gaat of ontstaat wordt aangeduid als het passieve substitutie-effect. Als het passieve substitutie-effect positief is, gaat het om extra baanopeningen als gevolg van tekorten bij andere opleidingen. Een negatief substitutie-effect duidt daarentegen op een verlies aan baanopeningen, omdat men verdrongen wordt door andere opleidingen. 
Uitgaande van de meest recente arbeidsmarktprognoses van het ROA, bedraagt de ITA voor de opleidingscategorie HBO landbouw in de prognoseperiode 20II-20I6 iets meer dan één. Dit betekent dat de toekomstige arbeidsmarktperspectieven tot 2016 voor recent afgestudeerden met een diploma in het HAO als redelijk getypeerd kunnen worden. De arbeidsmarktperspectieven voor het $\mathrm{HBO}$ als geheel kunnen goed genoemd worden. In vergelijking met schoolverlaters en afgestudeerden op andere opleidingsniveaus die eveneens over een diploma in de agrarische sector beschikken, zijn de vooruitzichten voor afgestudeerden van het $\mathrm{HAO}$ in enkele gevallen iets beter en in andere gevallen iets slechter. Zo zijn de middellange termijn perspectieven voor agrariërs op $\mathrm{HBO}$-niveau iets beter dan voor VMBO'ers en universitair afgestudeerden uit de agrarische sector. Op deze opleidingsniveaus zijn de arbeidsmarktperspectieven tot 2016 voor deze sector matig te noemen. De perspectieven voor degenen met een $\mathrm{MBO}$-diploma in de agrarische sector zijn daarentegen juist beter dan voor hun equivalenten van het HAO. Voor MBO'ers met een diploma in de agrarische sector zijn de vooruitzichten tot 2016 zelfs goed.

Tabel 3.1

Indicator Toekomstige Arbeidsmarktperspectieven (ITA) voor afgestudeerden van het Hoger Agrarisch Onderwijs tot 2016, per opleidingstype

\begin{tabular}{|l|r|r|}
\hline Opleiding: & Indicator & Typering \\
\hline HBO landbouw: & $\mathbf{1 , 0 4}$ & redelijk \\
\hline HBO landbouw en veeteelt & 1,03 & redelijk \\
\hline HBO milieukunde & 1,02 & redelijk \\
\hline Bron: ROA (AIS) & & \\
\hline
\end{tabular}

$\mathrm{Na}$ de vergelijkingen van de perspectieven met andere opleidingsniveaus en met andere sectoren binnen het $\mathrm{HBO}$ ligt de focus nu op de onderliggende opleidingstypen van het HAO. Tabel 3.I geeft een overzicht van de ITA voor de sector HBO landbouw $(\mathrm{I}, \mathrm{O} 4)$ als zodanig, alsook voor de twee onderscheiden onderliggende opleidingstypen binnen HBO landbouw: landbouw en veeteelt ( $\mathrm{I}, 03)$ en milieukunde (I,02). Bij landbouw en veeteelt moet, zoals de naam van dit opleidingstype al doet vermoeden, vooral gedacht worden aan opleidingen gericht op landbouw (i.e. tropisch, biologisch), plantenteelt, dierenmanagement en veehouderij. Onder het opleidingstype milieukunde valt een breed scala aan opleidingen als bijvoorbeeld tuin- en akkerbouw, bos- en natuurbeheer, milieukunde, en voedings- en levensmiddelentechnologie.

De redelijke arbeidsmarktperspectieven tot 2016 voor afgestudeerden van de opleidingscategorie $\mathrm{HBO}$ landbouw zijn eveneens van toepassing op beide onderliggende opleidingstypen: $\mathrm{HBO}$ landbouw en veeteelt en $\mathrm{HBO}$ milieukunde. Hoewel er voor $\mathrm{HBO}$ landbouw en veeteelt in de prognoseperiode een lage vervangingsvraag en uitbreidingsvraag voor dit opleidingstype voorzien worden is het toekomstig arbeidsmarktperspectief tot 2016 toch redelijk. Dit komt doordat hier ook maar weinig nieuwe instromers tegenover staan. Voor afgestudeerden van opleidingen die geclassificeerd kunnen worden als $\mathrm{HBO}$ milieukunde zal er de komende jaren sprake zijn 
van een gemiddelde uitbreidingsvraag, terwijl er naar verwachting een erg lage vervangingsvraag zal zijn. Wanneer de baanopeningen die dientengevolge ontstaan worden afgezet tegen de lage arbeidsmarktinstroom van personen met een diploma $\mathrm{HBO}$ milieukunde, dan resulteert dit voor deze afgestudeerden in een redelijk toekomstig arbeidsmarktperspectief op de middellange termijn. 



\section{Vereiste competenties voor afgestudeerden van het HAO}

In hoofdstuk 2 werd een korte schets gegeven van de arbeidsmarkt voor HAO'ers in het verleden en het heden, en in hoofdstuk 3 werden prognoses gepresenteerd van de verwachte ontwikkeling van de werkgelegenheid in de toekomst. Deze vooral kwantitatieve ontwikkelingen zijn interessant en belangrijk, maar zeggen weinig of niets over hoe het werk in de toekomst in kwalitatieve zin eruit zal zien. In dit hoofdstuk komt aan bod hoe het onderwijsveld op de te verwachten trends kan inspelen bij het opleiden van toekomstige arbeidskrachten voor de agrarische sector. De focus ligt hierbij op de competenties waar het onderwijsveld zich op moet gaan richten. In paragraaf 4.I komt het vereiste competentieniveau aan bod van recent afgestudeerden die werkzaam zijn in hun kerndomein. Bovendien wordt hier besproken of bepaalde competenties door de jaren heen belangrijker zijn geworden. In paragraaf 4.2 komen vervolgens de ervaren competentietekorten aan bod.

\subsection{Vereist niveau competenties}

Gebruikmakend van gegevens uit de HBO-Monitor wordt in deze paragraaf ingegaan op het competentieniveau dat vereist is voor afgestudeerden van het Hoger Agrarisch Onderwijs die in hun kerndomein werkzaam zijn (aansluiting opleiding-werk naar zowel opleidingsniveau als opleidingsrichting). Tabel 4.I toont het aandeel van de afgestudeerden die hebben aangegeven dat de desbetreffende competentie op een hoog niveau is vereist (antwoord 4 of 5 op een 5-puntschaal die loopt van I 'matig niveau vereist' $\mathrm{t} / \mathrm{m} 5$ 'uitmuntend niveau vereist'). Hierbij wordt de groep afgestudeerden van het $\mathrm{HAO}$ vergeleken met de totale groep afgestudeerde HBO'ers. De data voor de totale groep pas afgestudeerde HBO'ers zijn herwogen om een zo eerlijk mogelijke vergelijking tussen beide groepen te waarborgen. ${ }^{\text {II }} \mathrm{Om}$ een beeld te krijgen van de mate waarin de competentievereisten aan het veranderen zijn, wordt tevens de

II. Hiervoor zijn de data voor $\mathrm{HBO}$ totaal vermenigvuldigd met een factor die gelijk is aan het deel van het $\mathrm{HBO}$ dat bestaat uit recent afgestudeerden van het HAO. Op deze manier wordt voorkomen dat er significante verbanden gevonden worden, enkel door het feit dat er voor het totale HBO met zulke grote aantallen gerekend wordt. 
trend in deze vereisten berekend, m.a.w. de gemiddelde toe- of afname per jaar. De trend wordt alleen getoond wanneer deze statistisch significant is. ${ }^{12}$

\section{Tabel 4.1}

Vereist competentieniveau voor HAO en HBO totaal, 2004-2010*

\begin{tabular}{|c|c|c|c|c|}
\hline & \multicolumn{2}{|c|}{$\mathrm{HAO}$} & \multicolumn{2}{|c|}{ HBO totaal } \\
\hline & gem. & trend & gem. & trend \\
\hline \multicolumn{5}{|l|}{ Kennis van: } \\
\hline eigen vakgebied & 3,8 & 0,049 & 3,8 & n.s. \\
\hline andere vakgebieden & 3,3 & n.s. & 3,3 & n.s. \\
\hline \multicolumn{5}{|l|}{ Vermogen om: } \\
\hline vakkennis in praktijk toe te passen & 3,9 & n.s. & 3,9 & n.s. \\
\hline informatie- \& communicatietechnologie te gebruiken & 3,7 & n.s. & 3,6 & n.s. \\
\hline in buitenlandse talen te communiceren & 2,7 & n.s. & 2,5 & n.s. \\
\hline informatie te vergaren & 3,9 & n.s. & 3,9 & n.s. \\
\hline problemen en kansen te signaleren & 4,1 & n.s. & 4,1 & n.s. \\
\hline verbanden te leggen tussen verschillende zaken & 4,0 & n.s. & 4,0 & n.s. \\
\hline hoofd-van bijzaken te onderscheiden & 3,8 & n.s. & 3,9 & n.s. \\
\hline logisch te redeneren & 4,0 & n.s. & 4,0 & n.s. \\
\hline conform budget, planning of richtlijnen te werken & 3,7 & n.s. & 3,6 & n.s. \\
\hline onder druk goed te functioneren & 4,0 & n.s. & 4,0 & n.s. \\
\hline knopen door te hakken & 3,8 & n.s. & 3,7 & n.s. \\
\hline nieuwe ideeën en oplossingen te bedenken & 3,9 & n.s. & 3,9 & n.s. \\
\hline nieuwe dingen te leren & 3,9 & n.s. & 4,0 & n.s. \\
\hline aan anderen duidelijk te maken wat men bedoelt & 4,1 & n.s. & 4,2 & n.s. \\
\hline productief met anderen samen te werken & 3,9 & n.s. & 4,0 & n.s. \\
\hline capaciteiten van anderen aan te spreken & 3,7 & n.s. & 3,7 & n.s. \\
\hline zelfstandig de werkzaamheden uit te voeren & 4,3 & n.s. & 4,3 & n.s. \\
\hline \multicolumn{5}{|l|}{ Bereidheid om: } \\
\hline de nek uit te steken & 3,8 & n.s. & 3,8 & n.s. \\
\hline eigen en andermans ideeën ter discussie te stellen & 3,9 & n.s. & 3,8 & n.s. \\
\hline voor eigen standpunt op te komen & 3,9 & n.s. & 3,8 & n.s. \\
\hline begrip te tonen voor andere standpunten & 3,9 & n.s. & 3,9 & n.s. \\
\hline
\end{tabular}

* Gemiddeld antwoord van afgestudeerden op 5-puntsschaal (1'matig t/m 5'uitmuntend')

Trends worden alleen weergegeven wanneer deze significant zijn op minimaal 5\%-niveau.

Data voor $\mathrm{HBO}$ totaal zijn herwogen.

Bron: HBO-Monitor 2004-2010

I2. De trends zijn berekend door middel van 23 afzonderlijke regressieanalyses waarbij het vereiste competentieniveau de afhankelijke variabele is. Telkens is het effect van het aantal jaren verstreken vanaf 2004 $(2004=0, \ldots$ 20IO=6) berekend op het vereiste niveau van de verschillende competenties. Om het effect zo zuiver mogelijk te houden zijn eventuele verschuivingen in de compositie van de sector naar opleiding of hogeschool uitgebannen, door in de analyse een dummy op te nemen voor elke opleiding en school die in de sector is vertegenwoordigd. 
In tabel 4.I is te zien dat $\mathrm{HAO}$ afgestudeerden het vereiste niveau van de competentie 'het vermogen om zelfstandig werkzaamheden uit te voeren' het hoogst inschatten $(4,3)$. Ook van de competenties vermogen om problemen en kansen signaleren, vermogen om aan anderen duidelijk te maken wat men bedoelt, vermogen om verbanden te leggen tussen verschillende zaken, vermogen om logisch te redeneren en vermogen om onder druk te functioneren schatten de HAO'ers in dat het vereiste niveau vrij hoog is. Het vereiste niveau van de competentie kennis van andere vakgebieden en, in het bijzonder, het vermogen om in buitenlandse talen te communiceren wordt door de HAO'ers het minst hoog ingeschat, hoewel dit vereiste niveau nog altijd hoger is dan voor het $\mathrm{HBO}$-gemiddelde. Dit zou te maken kunnen hebben met de relatief grote groep afgestudeerden van het HAO die in het buitenland stage heeft gelopen (zie hoofdstuk I).

Tussen 2004 en 2010 wijkt het vereiste competentieniveau van afgestudeerden van het $\mathrm{HAO}$ nauwelijks af van dat van het totale $\mathrm{HBO}$. Ook voor het $\mathrm{HBO}$-gemiddelde is het vereiste niveau het hoogst wat betreft het zelfstandig kunnen werken, aan anderen duidelijk kunnen maken wat men bedoelt en het signaleren van problemen en kansen, en is het vereiste niveau het laagst voor het communiceren in buitenlandse talen en de kennis van andere vakgebieden. Hoewel het belang dat aan competenties wordt toegekend in grote lijnen overeenkomt, zijn er marginale verschillen waarneembaar in het vereiste competentieniveau van $\mathrm{HAO}$-afgestudeerden ten opzichte van het $\mathrm{HBO}$-gemiddelde. Bij I4 van de 23 in de vragenlijst opgenomen competenties ligt het vereiste niveau volgens $\mathrm{HAO}$-afgestudeerden ietwat hoger dan volgens de totale groep afgestudeerde HBO'ers, bij 7 competenties is dit voor het HAO iets lager dan gemiddeld en bij 2 competenties geven beide groepen een exact hetzelfde vereist niveau aan. Hoewel het HAO qua gemiddeld vereist competentieniveau niet veel van het $\mathrm{HBO}$-gemiddelde afwijkt, is de relatieve positieve afwijking van $\mathrm{HAO}$ ten opzichte van het $\mathrm{HBO}$-gemiddelde het grootst voor de competenties: eigen en andermans ideeën ter discussie stellen, conform budget, planning of richtlijnen werken en communiceren in een buitenlandse taal. Voor deze competenties is het vereiste niveau dat door HAO'ers wordt aangeven hoger dan het HBO-gemiddelde. Wat betreft het productief met anderen samenwerken is het vereiste niveau bij het HAO in vergelijking met het $\mathrm{HBO}$-gemiddelde relatief gezien juist het laagst. Het verschil is echter nihil (-o,I).

Opvallend is dat de cijfers impliceren dat onder HAO'ers het vereiste niveau van slechts één competentie de afgelopen periode significant veranderd is; de kennis van het eigen vakgebied. Het positieve effect voor de jaren die verstreken zijn sinds 2004 op het vereiste competentieniveau voor de kennis van het eigen vakgebied wil zeggen dat recent afgestudeerden van het HAO in deze periode ervaren hebben dat de lat steeds hoger gelegd wordt wat betreft de kennis die zij moeten bezitten over het eigen vakgebied. Dit is in tegenstelling tot andere $\mathrm{HBO}$ sectoren, waar voor meerdere competenties significante ontwikkelingen in het vereiste niveau gevonden worden. Zeer waarschijnlijk ligt hier grotendeels aan ten grondslag dat het in deze sector 
om kleinere aantallen gaat waardoor er minder snel significante verbanden worden gevonden.

Eenzelfde verklaring is waarschijnlijk van toepassing op de trends in het vereiste competentieniveau van het gehele $\mathrm{HBO}$ in deze tabel. Dat deze trends niet significant zijn voor de totale groep recent afgestudeerde HBO'ers lijkt op het eerste oog vreemd omdat het bij $\mathrm{HBO}$ totaal doorgaans om veel grotere aantallen gaat. Aangezien er echter een herweging is gemaakt voor de data van het totale $\mathrm{HBO}$ om een eerlijkere vergelijking met het $\mathrm{HAO}$ mogelijk te maken, lijkt dit toch een plausibele verklaring. De data voor $\mathrm{HBO}$ totaal zijn vanuit dit oogpunt vermenigvuldigd met een factor 0,03 , i.e. het aandeel HAO-afgestudeerden in deze dataset. Dit verklaart waarom ook in deze analyses met kleine aantallen wordt gerekend en er dus minder snel significante ontwikkelingen gevonden worden.

\subsection{Competentietekorten}

Het is de vraag hoe het onderwijs op het hoge vereiste niveau van bepaalde competenties heeft gereageerd. Tabel 4.2 toont de competentietekorten zoals deze ervaren worden door afgestudeerden die in hun kerndomein werkzaam zijn. De resultaten worden vergeleken tussen het $\mathrm{HAO}$ en het totale $\mathrm{HBO}$. Omdat in de HBO-Monitor zowel het vereiste competentieniveau als het eigen competentieniveau op eenzelfde 5-puntschaal (die varieert van I 'matig' tot 5 'uitmuntend') is gemeten, geeft de verschilscore voor iedere competentie een indicatie van een eventueel tekort of overschot. Van een competentietekort is sprake wanneer het vereiste niveau hoger is dan het eigen niveau. Het is belangrijk op te merken dat een tekort niet noodzakelijkerwijs negatief hoeft te zijn. Wanneer er namelijk sprake is van een klein tekort wordt dit vaak ervaren als een uitdaging om dit punt te verbeteren. Wanneer afgestudeerden met betrekking tot een bepaalde competentie het gevoel hebben dat zij al een bepaald niveau bereikt hebben, zouden zij wel eens gemakzuchtig kunnen worden en geen noodzaak zien om zich te blijven ontwikkelen op dat punt. Wel kan er een signaalfunctie van deze tekorten uitgaan. Net als bij het vereiste niveau wordt tevens de trend in tekorten, m.a.w. de gemiddelde jaarlijkse toe- of afname weergegeven. De trend wordt berekend op dezelfde wijze als bij het vereist competentieniveau (tabel 4.I) en wordt alleen weergegeven wanneer deze statistisch significant is. De eerste kolom van tabel 4.2 geeft voor elk van de 23 verschillende competenties weer welk deel van de agrariërs die in het kerndomein werkzaam zijn een tekort ervaart op de betreffende competentie.

De competentie waar de grootste groep HAO'ers ervaart dat het eigen niveau lager is dan het vereiste niveau, is het vermogen om het aan anderen duidelijk kunnen maken wat men bedoelt. Tussen 2004 en 2010 ervaart bijna 4 op de Io in het kerndomein werkende HAO'ers een tekort op deze competentie. Ook een relatief grote groep afgestudeerde HAO'ers ervaart een tekort in kennis van het eigen vakgebied $(38,5 \%)$ en 
het vermogen om problemen en kansen te signaleren (35,2\%). Andere competenties waarvoor meer dan 3 op de Io recent afgestudeerde HAO'ers een competentietekort ervaren zijn: het vermogen om onder druk goed te functioneren, bereidheid om voor het eigen standpunt op te komen, vermogen om conform budget, planning of richtlijnen te werken, en het vermogen om knopen door te hakken. Er zijn daarnaast vijf competenties waarvoor minder dan twintig procent van de HAO'ers aangeeft dat het eigen niveau lager is dan het vereiste niveau. Doorgaans blijken afgestudeerden van het $\mathrm{HAO}$ vrij goed in staat om zelf informatie te vergaren, begrip te tonen voor andere standpunten, hun nek uit te steken, informatie- en communicatietechnologie te gebruiken, en nieuwe dingen te leren.

\section{Tabel 4.2}

Ervaren tekorten met betrekking tot competenties*, 2004-2010

\begin{tabular}{|c|c|c|c|c|}
\hline & \multicolumn{2}{|l|}{ HAO } & \multicolumn{2}{|c|}{ HBO totaal } \\
\hline & gem. & trend & gem. & trend \\
\hline \multicolumn{5}{|l|}{ Kennis van: } \\
\hline eigen vakgebied & 38,5 & 2,546 & 36,5 & n.s. \\
\hline andere vakgebieden & 26,8 & $-2,233$ & 25,8 & n.s. \\
\hline \multicolumn{5}{|l|}{ Vermogen om: } \\
\hline vakkennis in praktijk toe te passen & 29,3 & n.s. & 28,6 & n.s. \\
\hline informatie- \& communicatietechnologie te gebruiken & 18,0 & n.s. & 15,9 & n.s. \\
\hline in buitenlandse talen te communiceren & 22,6 & n.s. & 14,3 & n.s. \\
\hline informatie te vergaren & 19,4 & n.s. & 17,6 & n.s. \\
\hline problemen en kansen te signaleren & 35,2 & n.s. & 33,2 & n.s. \\
\hline verbanden te leggen tussen verschillende zaken & 28,2 & n.s. & 27,3 & n.s. \\
\hline hoofd- van bijzaken te onderscheiden & 26,9 & n.s. & 27,5 & n.s. \\
\hline logisch te redeneren & 20,2 & n.s. & 18,3 & n.s. \\
\hline conform budget, planning of richtlijnen te werken & 30,5 & n.s. & 27,3 & n.s. \\
\hline onder druk goed te functioneren & 31,2 & n.s. & 28,6 & n.s. \\
\hline knopen door te hakken & 30,3 & n.s. & 29,1 & n.s. \\
\hline nieuwe ideeën en oplossingen te bedenken & 29,6 & n.s. & 28,9 & n.s. \\
\hline nieuwe dingen te leren & 17,3 & n.s. & 15,3 & n.s. \\
\hline aan anderen duidelijk te maken wat men bedoelt & 39,1 & n.s. & 33,3 & n.s. \\
\hline productief met anderen samen te werken & 21,1 & 2,225 & 17,4 & n.s. \\
\hline capaciteiten van anderen aan te spreken & 27,2 & n.s. & 28,3 & n.s. \\
\hline zelfstandig de werkzaamheden uit te voeren & 21,3 & n.s. & 21,1 & n.s. \\
\hline \multicolumn{5}{|l|}{ Bereidheid om: } \\
\hline de nek uit te steken & 18,4 & n.s. & 17,2 & n.s. \\
\hline eigen en andermans ideeën ter discussie te stellen & 25,7 & n.s. & 24,1 & n.s. \\
\hline voor eigen standpunt op te komen & 31,1 & n.s. & 26,5 & n.s. \\
\hline begrip te tonen voor andere standpunten & 19,2 & $-2,032$ & 15,9 & n.s. \\
\hline
\end{tabular}

* Vereist niveau is hoger dan eigen niveau

Trends worden alleen weergegeven wanneer deze significant zijn op minimaal 5\%-niveau.

Data voor $\mathrm{HBO}$ totaal zijn herwogen.

Bron: HBO-Monitor 2004-2010 
In tegenstelling tot de andere sectorrapportages zijn er bij het HAO de afgelopen jaren slechts enkele significante trends waarneembaar op het gebied van competentietekorten. Ook hier speelt het kleine aantal data een voorname rol. Er zijn tussen 2004 en 2010 twee significante stijgende trends in ervaren competentietekorten: kennis van eigen vakgebied en het vermogen om productief met anderen samen te werken. Met name de eerste (kennis van eigen vakgebied) is opvallend, aangezien daar een significant stijgend vereist niveau werd geconstateerd. Dat betekent dat het ervaren vereiste niveau is gestegen, maar dat de eigen competenties niet (in dezelfde mate) zijn mee gestegen.

Tussen 2004 en 2010 zijn er daarnaast twee significant dalende trends in ervaren competentietekorten: kennis van andere vakgebieden en bereidheid om begrip te tonen voor andere standpunten. Het vereiste niveau van beide competenties was in dezelfde periode niet uitzonderlijk hoog maar toch ook zeker niet laag te noemen (3.3, respectievelijk 3.9). Ook is het gemiddelde percentage afgestudeerde HAO'ers dat een tekort ervaart op beide competenties aan de lage kant. Dit geeft aan dat het onderwijs er in de afgelopen jaren steeds beter in lijkt te slagen om HAO'ers het (niet uitzonderlijk hoge) niveau van deze twee competenties te laten bereiken.

De drie competenties waar de grootste groep afgestudeerden tekorten ervaren, zijn hetzelfde voor het $\mathrm{HAO}$ als voor het $\mathrm{HBO}$-gemiddelde: kennis van eigen vakgebied, vermogen om problemen en kansen te signaleren en vermogen aan andere duidelijk te maken wat men bedoelt. Toch is het percentage afgestudeerde HAO'ers dat een competentietekort ervaart niet alleen bij deze drie competenties, maar bij vrijwel alle overige competenties, hoger dan het $\mathrm{HBO}$-gemiddelde. Van de 23 verschillende competenties zijn er slechts twee waarvoor geldt dat HAO'ers minder vaak competentietekorten ervaren dan gemiddeld, te weten: het vermogen om hoofd- en bijzaken te onderscheiden en het vermogen om capaciteiten van anderen aan te spreken. Het $\mathrm{HAO}$ wijkt het meest van het $\mathrm{HBO}$-gemiddelde af wat betreft de ervaren tekorten van afgestudeerden aangaande het communiceren in buitenlandse talen. Van de recent afgestudeerden van het HAO die werkzaam zijn in hun kerndomein zegt 22,6\% dat het eigen niveau voor deze competentie lager is dan het voor de functie vereiste niveau, terwijl dit voor het totale $\mathrm{HBO}_{\mathrm{I}}, 3 \%$ is; een verschil van $8,3 \%$-punt. Verder geven recent afgestudeerde HAO'ers, in vergelijking met andere HBO'ers, duidelijk vaker aan een competentietekort ervaren wat betreft het vermogen aan anderen duidelijk te maken wat men bedoelt, het vermogen om voor het eigen standpunt op te komen, en het vermogen om productief met anderen samen te werken. 


\section{Conclusie}

Het Hoger Agrarisch Onderwijs is veruit de kleinste van alle $\mathrm{HBO}$ sectoren. Op de meeste arbeidsmarktindicatoren scoren de agrarische opleidingen slechter dan of gelijk aan het $\mathrm{HBO}$-gemiddelde. De enige indicatoren waarop ze beter dan gemiddeld scoren zijn de werkloosheidspercentages in tijden waarin het economisch wat beter gaat (in tijden van laagconjunctuur is de werkloosheid onder HAO'ers echter hoger dan gemiddeld), het relatief hoge aandeel HAO'ers met een fulltime aanstelling, en sinds 2008 de tevredenheid met de huidige functie. Daarentegen hebben recent afgestudeerden van het $\mathrm{HAO}$ vaker dan gemiddeld een tijdelijke aanstelling, werken ze minder vaak binnen hun kerndomein en ligt hun reële bruto uurloon structureel onder het $\mathrm{HBO}$-gemiddelde.

De toekomstige arbeidsmarktperspectieven zijn voor afgestudeerden van het HAO redelijk, terwijl die voor de gemiddelde HBO'er goed zijn. Hoewel relatief veel HAO'ers afkomstig zijn van een vooropleiding op MBO-niveau, zijn de arbeidsmarktperspectieven voor agrarische $\mathrm{MBO}$ opleidingen beter dan voor de agrarische opleidingen op HBO niveau. Vergeleken met agrarische opleidingen in het VMBO en het WO zijn de arbeidsmarktperspectieven van het $\mathrm{HAO}$ echter juist beter.

Het vereiste niveau van de competentie 'kennis van eigen vakgebied' is de afgelopen jaren significant gestegen voor afgestudeerden van het HAO. Het vereiste niveau van de volgende competenties is hoog voor HAO'ers, maar veranderingen kunnen niet significant worden aangetoond:

- Vermogen om problemen en kansen te signaleren

- Vermogen om verbanden te leggen tussen verschillende zaken

- Vermogen om logisch te redeneren

- Vermogen om onder druk goed te functioneren

- Vermogen om aan anderen duidelijk te maken wat u bedoelt

- Vermogen om zelfstandig werkzaamheden uit te voeren

Ervaren competentietekorten geven aan waar hogescholen in de toekomst meer aandacht aan zouden kunnen besteden bij de inhoud van het agrarisch onderwijs. De analyses wijzen uit dat zo'n 39\% van de afgestudeerde HAO'ers een competentietekort ervaart op de belangrijker wordende competentie 'kennis van eigen vakgebied'. Het 
lijkt erop dat het agrarisch onderwijs het stijgende vereiste niveau van kennis van het eigen vakgebied niet kan bijbenen.

Van de bovenstaande competenties waar een hoog niveau vereist wordt van HAO'ers, ondervindt zo'n 2I tot $39 \%$ een competentietekort. Het hoger agrarisch onderwijs zou met name aandacht kunnen besteden aan het opkrikken van het niveau van het vermogen aan anderen duidelijk te maken wat men bedoelt en het vermogen om problemen en kansen te signaleren, aangezien 39\% respectievelijk 35\% van de HAO'ers hier een competentietekort ervaart. Daarentegen zijn er ook twee competenties waar het hoger agrarisch onderwijs er wel in geslaagd is om het (niet uitzonderlijk hoge) vereiste niveau aan hun afgestudeerden bij te brengen, te weten: kennis van andere vakgebieden en de bereidheid om begrip te tonen voor andere standpunten. 


\section{Bijlage: Kernindicatoren voor HAO Bachelor-opleidingen}

\section{Tabel B1}

Vijf kernindicatoren voor HAO Bachelor-opleidingen, 2006-2010

\begin{tabular}{|c|c|c|c|c|c|c|}
\hline HAO Bachelor-opleiding & Werkloosheid & $\begin{array}{r}\text { Werkzaam in } \\
\text { kerndomein } \\
\%\end{array}$ & $\begin{array}{r}\text { gem. } \\
\text { Bruto } \\
\text { uurloon } \\
€\end{array}$ & $\begin{array}{r}\text { Spijt } \\
\text { opleiding } \\
\%\end{array}$ & $\begin{array}{r}\text { Tevreden } \\
\text { met } \\
\text { functie } \\
\%\end{array}$ & Aantal \\
\hline Bedrijfskunde Groene sector & 4,7 & 60,3 & 13,13 & 19,7 & 72,4 & 425 \\
\hline Educatie Groene sector & 1,1 & 67,7 & 13,86 & 19,6 & 66,1 & 156 \\
\hline Groene ruimte & 4,3 & 69,9 & 14,34 & 17,7 & 69,5 & 660 \\
\hline Landbouw & 7,2 & 56,0 & 12,03 & 23,0 & 71,1 & 1.114 \\
\hline Technologie Groene sector & 4,5 & 80,0 & 14,72 & 13,6 & 66,4 & 236 \\
\hline Totaal HAO Bachelor & 5,3 & 62,3 & 13,14 & 20,2 & 70,0 & 2.591 \\
\hline Totaal HBO Bachelor & 4,8 & 70,5 & 13,69 & 19,8 & 67,7 & 70.409 \\
\hline
\end{tabular}

\section{Toelichting}

- Werkloosheid: Het werkloosheidspercentage heeft betrekking op de werkloze beroepsbevolking: schoolverlaters zonder werk (of met werk van minder dan 12 uur per week) die op zoek zijn naar betaald werk. Daarbij is tevens als voorwaarde gesteld dat de maatschappelijke positie niet scholier of student is.

- Kerndomein: Het percentage dat aangeeft dat het door de werkgever vereiste opleidingsniveau minimaal HBO is en dat de door de werkgever vereiste opleidingsrichting overeenkomt met of verwant is aan de eigen opleidingsrichting.

- Bruto uurloon: Dit betreft het gemiddelde bruto inkomen in de hoofdfunctie. Dit is inclusief toeslagen maar exclusief inkomen uit overwerk. Er is hier niet gecorrigeerd voor verschillen in leeftijd van de schoolverlaters, maar wel voor inflatie.

- Spijt opleiding: Het percentage dat aangeeft achteraf gezien voor een andere opleiding op hetzelfde of ander niveau te hebben willen kiezen.

- Tevredenheid: Hoe tevreden bent u met uw huidige functie (1'zeer ontevreden' tot en met 5 'zeer tevreden'. Vermeld is het percentage van antwoordcategorie 4 en 5 . 